\title{
Public-private health and urban mobility partnerships in the State of Bahia: current situation, projects and main agents involved
}

\author{
MAINA PiRAJÁ SILVA ${ }^{1}$ \\ Silvana Sá de Carvalho ${ }^{1}$ \\ MARIANA de OLIVEIRA SANTANA ${ }^{1}$ \\ 1 Universidade Católica do Salvador (UCSAL) / Programa de Pós-graduação em Planejamento Territorial \\ E DESENVOLVIMENTO SOCIAL, SALVADOR - BA, BRAZIL
}

\begin{abstract}
This work aimed to identify the public-private partnerships (PPPs) existing in the state of Bahia, evaluating and comparing their effectiveness. Case studies of health and urban mobility partnerships were prepared by examining the structuring of projects, implementation and operation of contracts, the public and private agents involved and their connections. In addition, an analysis of these PPPs was carried out to understand the complexity of these contractual arrangements. The research was qualitative, exploratory, and descriptive, and used the methods of monographic and comparative procedures. The results showed that the State of Bahia has advanced in the provision of public services and infrastructure through these partnerships, with pioneering projects that encompass a heterogeneity of public and private agents (national and international), thus forming a dynamic power network. However, there are also criticisms of this type of partnership, on the risks of not fulfilling its purposes, in the governance system, and long-term risks for the financial obligations for future taxpayers.
\end{abstract}

Keywords: Public-Private Partnerships. PPP projects in Bahia. Public and private agents and their relations.

Parcerias público-privadas de saúde e mobilidade urbana no Estado da Bahia: atual conjuntura, projetos e principais agentes envolvidos

\section{Resumo}

O trabalho tem por objetivo identificar as parcerias público-privadas (PPPs) existentes no estado da Bahia; avaliar e comparar, por meio de estudos de caso das parcerias de saúde e mobilidade urbana, a efetividade delas mediante o exame da estruturação de projetos, implementação e funcionamento das concessões; e ponderar sobre os agentes públicos e privados envolvidos e suas articulações. Além disso, foi realizada uma análise dessas PPPs a fim de compreender a complexidade desses arranjos contratuais. A pesquisa utilizou uma metodologia qualitativa, de cunho exploratório e descritivo, empregando os métodos de procedimentos monográfico e comparativo. Os resultados mostraram que a Bahia tem avançado na provisão de serviços públicos e de infraestrutura por meio dessas parcerias, com projetos pioneiros que abrangem uma heterogeneidade de agentes públicos e privados, nacionais e internacionais, formando uma rede de poder dinâmica. No entanto, existem também críticas a esse tipo de parceria, em virtude dos riscos de não cumprimento de seus propósitos no sistema de governança e em longo prazo, pelas obrigações financeiras para os futuros contribuintes.

Palavras-chave: Parcerias público-privadas. Projetos de PPPs da Bahia. Agentes públicos e privados e suas relações.

Asociaciones público-privadas de salud y movilidad urbana en el estado de Bahía: coyuntura actual, proyectos y principales agentes involucrados

\section{Resumen}

El trabajo tuvo como objetivo identificar las asociaciones público-privadas (APP) existentes en el estado de Bahía para evaluar y comparar, a través de estudios de caso de las asociaciones de salud y movilidad urbana, su eficacia mediante el examen de la estructuración de proyectos, implementación y operación, así como considerar a los agentes públicos y privados involucrados y sus articulaciones. Además, se realizó un análisis de estas APP para comprender la complejidad de estos acuerdos contractuales. La investigación utilizó una metodología cualitativa, exploratoria y descriptiva, y empleó los métodos de procedimientos monográficos y comparativos. Los resultados mostraron que el estado de Bahía ha avanzado en la provisión de servicios públicos e infraestructura a través de estas asociaciones, con proyectos pioneros que abarcan una heterogeneidad de agentes públicos y privados (nacionales e internacionales), formando así una red dinámica de poder. Sin embargo, también hay críticas a este tipo de asociación, por los riesgos de incumplimiento de sus propósitos, en el sistema de gobernanza y a largo plazo, debido a las obligaciones financieras para los futuros contribuyentes.

Palabras clave: Asociaciones público-privadas. Proyectos de APP en Bahía. Agentes públicos y privados y sus relaciones. 


\section{INTRODUCTION}

With the different political and economic changes that have occurred in Brazil, especially in the 1980s and 1990s - periods marked by fiscal and financial crisis, productive restructuring, processes of political re-democratization, expansion of responsibilities to municipalities, introduction of neoliberalism and its advances that guide and support the strengthening of market action - a new context of political-institutional and economic reforms has emerged in the country, following an understanding of public management based on the establishment of public-private arrangements. Among these arrangements, public-private partnerships (PPPs) stand out as a type of enterprise that aims to attract the private sector to invest in areas in need, especially in relation to infrastructure and public services.

In this context, this study aims to identify the PPPs in the state of Bahia, evaluate and compare (through case studies) their effectiveness by examining their structures, implementations and operations of concessions, as well as consider the public and private agents involved and their pronunciations. In addition, these PPPs were analyzed to understand the complexity of their contractual arrangements.

For the case studies, 3 Health PPPs - Suburban Hospital (SH), Couto Maia Institute Hospital (CMIH) and Diagnostic Imaging and 3 Urban PPPs - Salvador-Lauro de Freitas Metro System (SLMS), BA-052 Road System (Estrada do Feijão) and Light Rail Vehicle(Suburban VLT- monorail). The West Road System (SVO) mobility PPP, which is part of the Salvador-Itaparica Bridge, was not analyzed because its contract has not yet been signed.

Bahia, which is located in the Northeast region of Brazil, was chosen because the state has invested and attracted a lot of capital to implement this type of institutional arrangement, following the new order of the country. To this end, it has relaxed its regulatory framework, creating opportunities to shelter financialization with lower barriers to capital action. The basis of their actions includes the discourse of urban entrepreneurship and competition with other major states in the region, especially Pernambuco and Ceará.

In order to systematize the research, this article was divided into eight sections, starting with this introduction (first section). The second section describes the research methodology; the third provides a the literature review, the fourth reports on the regulatory framework of PPPs in Brazil, especially Bahia, the fifth presents the PPPs that currently exist in the state; the sixth shows an evaluation of projects, agents and their articulations from six case studies related to health and urban mobility PPPs; the seventh presents an analysis of these PPPs; and the eighth section includes final considerations about the study.

\section{METHODOLOGY}

Regarding methodology, this study followed an exploratory-descriptive qualitative approach and used comparative and monographic procedures. Therefore, the following steps based on methods adopted by Silva, Carvalho and Oliveira (2019), were used and are synthesized in Figure 1:

1) National and international bibliographic survey: books, book chapters, dissertations, theses, well-qualified articles and events.

2) Document review of norms and laws from Brazil, specifically Bahia, about PPPs, on official state and federal government websites.

3) Obtaining official documents for the PPP projects in Bahia.

4) Survey of newspaper articles about projects and businesses.

5) Collecting data about PPPs from case studies.

6) Survey of public and private agents involved in the structuring of projects and throughout the life cycle of these concessions, to understand their articulations.

7) Groupings and building a database.

8) Critical reading and recording of all the surveys mentioned above.

9) Definition of four stages of PPP analysis:

a) The first consisted of the general profile of Bahian PPPs, analyzing their regulatory framework and their political-organizational structure, as well as the guarantee systems for financial obligations. 
b) The second led to a comparative assessment of the effectiveness of health and urban mobility projects, considering the structuring, bidding, implementation and business operations, as well as examining the pronunciations of the different agents that make up the PPPs.

c) The third involved semi-structured interviews of people linked to the state government and concessionaires. ${ }^{1}$

d) The fourth analyzed characteristics, laws and norms, guarantees and credibility of the government, project phases and their frameworks, relationship between public and private entities, invested capital, compensation system, greater responsibilities and risk allocation, as well as occasional problems and conflicts encountered.

10) Writing the article sections.

Figure 1

Synthesis of methodology

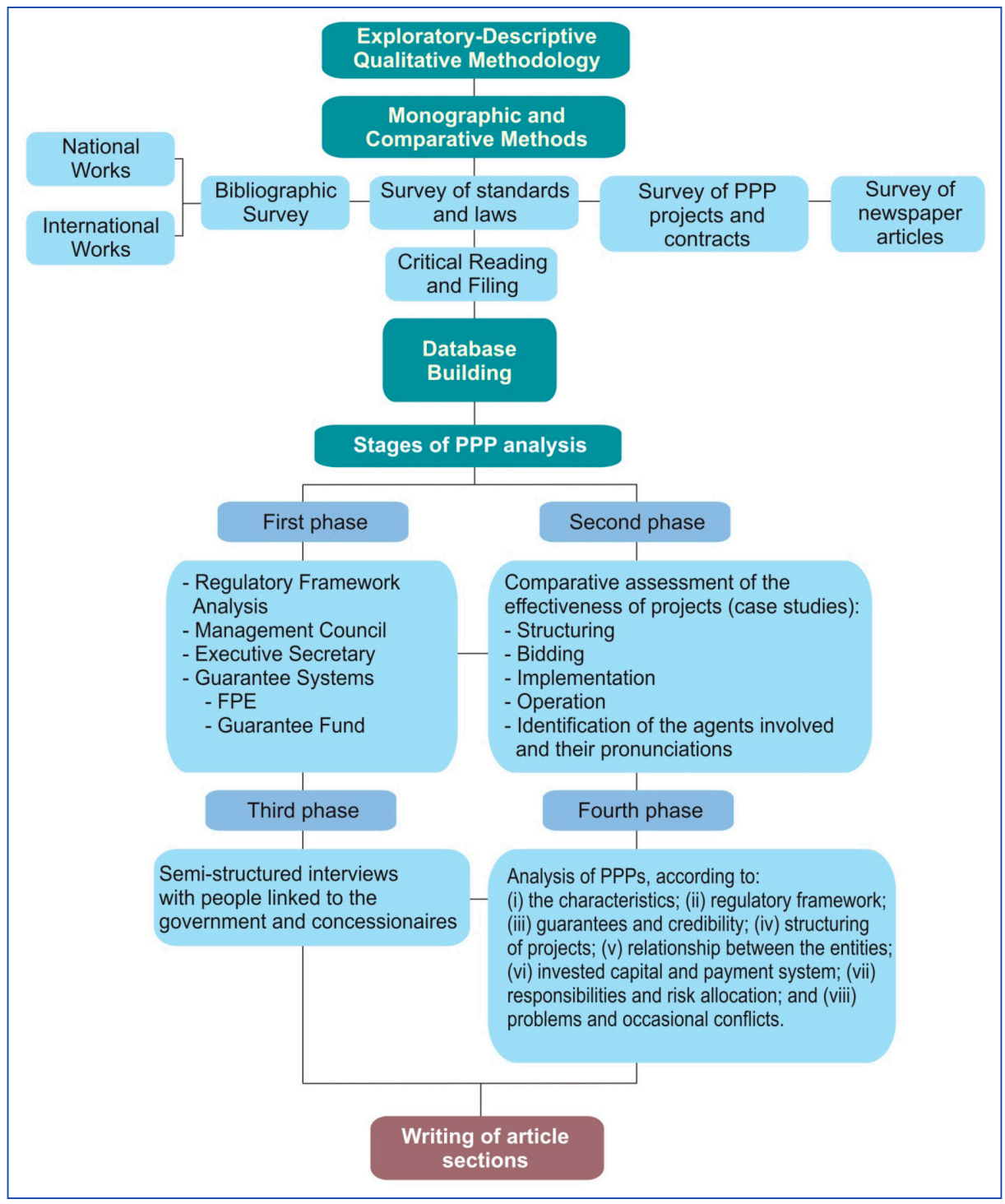

Source: Elaborated by the authors.

\footnotetext{
${ }^{1}$ Researchers chose to use non-probabilistic snowball sampling. 13 representatives were interviewed: 7 linked to public agencies Sesab, Sedur, Sefaz and Desenbahia; 6 linked to the businesses Prodal Health Consortium S/A, Couto Maia Constructions and Non-clinical Services Consortium S/A, Brazilian Diagnostic Network Consortium S/A (RBD Imagem) and CCR Metrô Bahia, all of whom were active members of the businesses. The positions and names of these people are not disclosed, and the interviews did not include all the PPPs. Of these 13 interviewees, only 4 did not permit recording, even though researchers presented an ethical term of free and informed consent that guaranteed the confidentiality and privacy of individuals by protecting their image and voice, and guaranteed non-use of information without the consent and/or to the detriment of the interviewee. All interviews were fully transcribed. Subsequently, these transcriptions were weighted following the content analysis methodology.
} 


\section{LITERATURE REVIEW}

Public-private partnerships are not new. In the 19th century, for example, France and the United States had already been using concessions for road construction and management. In the same century, India built the Princess Docks (port of Bombay) with the private sector, just as the Canadian government hired a company to build, manage and operate the TransCanada railway (SIEMIATYCKI, 2012).

However, from the 1990s onward, the PPP modality became a key word for public policy (OSBORNE, 2000). Today, they are present on all continents, despite the political regime, legal principles and the development conditions, resulting in significant changes in governance and the provision of infrastructure and public services.

According to Coghill and Woodward (2005), although PPPs are presented to the public as technical works, they are political decisions. PPPs are contractual arrangements that are part of a set of neoliberal structural reforms aimed at resizing the public sector in financing and reducing expenses and bottlenecks for infrastructure and public services.

Several scholars, both national and foreign, have different views about this type of contractual arrangement. According to Khanom (2010), for some they are administration or management tools, focused on organizational aspects to share risks, costs and resources, while others treat them as a tool for financial arrangements - reducing pressure on government budgets by privately financing infrastructure. As a development strategy, PPPs maximize development benefits through collaboration and efficiency associated with urban renewal and economic development, or even as a discursive term or a "language game", treated as a buzzword, designed to cover up other strategies and purposes, such as privatization.

A diverse range of international organizations are responsible for disseminating this type of enterprise, such as the World Bank Group, the International Monetary Fund (IMF) and the Inter-American Development Bank (IDB). The World Bank Group has a broad support policy in Latin America and the Caribbean, aiming to assist in project modeling in terms of financing infrastructure and development plans. In the view of Santos, Souza and Abreu $(2018$, p. 18) "[...] these combinations denote the relentless pursuit for international capital to insert itself in the most distant territories and search for profit, management and interference in corporate relations".

PPPs differ in terms of definition, structure and legal framework in different countries. In the extensive national and foreign literature, several models have been adopted. The United Kingdom, for example, was a pioneer (methodology and procedures) in implementing this type of partnership as early as the 1990s. For them, PPPs are defined as an association established between public and private sector entities - thus, there are several PPP modalities. Among them, the one that comes closest to the structure of Brazilian PPPs is the Private Finance Initiative (PFI) program, created in 1992, which has been adjusted over the years and aims to establish long-term infrastructure and public service arrangements (ZHENG, ROEHRICH and LEWIS, 2008). Its adoption is justified by the expectation of improving public services, imposing quality criteria on the private partner; improving money value (efficiency) in the use of public resources to benefit the population; decreasing public expenditure; risk transferring and sharing with the private sector; and private sector financing (AZEVEDO, 2008; PECl and SOBRAL, 2007, p. 2).

Inspired by the aforementioned model, in the 1990s, countries such as the United States, Japan and Australia instituted PPPs aimed at providing infrastructure (HODGE and GREVE, 2009), along with other European countries, such as Portugal, where the government started a broad PPP program during the second half of the 1990s, especially in road infrastructure projects (FIRMINO, 2018). European nations, such as France and Italy, still stand out in relation to the creation of legal instruments (AZEVEDO, 2008).

The number of partnerships and business flow are immense in Europe, with contracts totaling billions of Euros, especially the so-called long-term infrastructure contracts (LTICS) (HODGE and GREVE, 2009; WORLD BANK, 2013; ZHENG, ROEHRICH and LEWIS, 2008), with greater notoriety in the UK, Spain, France and Portugal. 
In general, PPPs have been evaluated positively since their creation (PECl and SOBRAL, 2007). However, some authors, such as Edwards, Shaoul, Stafford et al. (2004), highlight experiences that vary in terms of success. For example, in England, several projects had to be rescued, some discarded and others were subjected to widespread criticism. The most obvious failures were directed at costs and excess time.

Fernandez, Hillbrecht, Menezes et al. (2015) point out that the proper use of these concessions depends on several criteria of effectiveness and governance adopted by the public. Institutional factors, such as corruption control, political stability, credibility, transparency and the ability to comply with contracts, are fundamental for this type of business.

On the other hand, Brazil has also followed this new world order. The scenario for the introduction of PPPs includes different political and economic changes that occurred in the country, especially in the 1980s and 1990s, which were marked by fiscal and financial crises - caused by increased inflation and public debt -, productive restructuring, political democratization, expansion of responsibilities to municipalities (Constitution of 1988) and introduction of neoliberalism.

In this context, the country has undergone a series of reforms aimed at reducing the State. In the 1990s, the government of Fernando Collor de Mello instituted the National Privatization Program (PND) (Law No. 8.031/1990), later changed to National Privatization Council (Law No. 9.491/1997), under the government of Fernando Henrique Cardoso, aiming to privatize several state-owned companies in the country. However, according to Martimort and Pouyet (apud FERNANDEZ, HILLBRECHT, MENEZES et al., 2015, p. 294),

[...] experience [...] has shown that total privatization can be seen as an excessive response to inefficiency of the public sector. As these authors report, a more pragmatic approach should be adopted, which consists of providing efficient partnerships between governments and companies for the provision of main public services.

Likewise, the PND standardized the General Public Service Concessions Law (Law No. 8,987/1995). ${ }^{2}$ For this type of concession, the government determines the general rules, and the services are provided by the private sector (LIMA and COELHO, 2015). In this situation, management contracts with Social Organizations ([OS] Law No. 9.637/1998) and terms of partnership with Civil Society Organizations of Public Interest (Oscip) (Law No. 9.790/1999) stand out, as well as the Urban Operation Consortium (OUC), originally called Urban Operation and supported by the City Statute (Law No. 10.257/2001), which aims to make urban parameters more flexible and carry out a set of structural interventions.

In 2004, however, under Luiz Inácio Lula da Silva, the federal government enacted the Public-Private Partnerships Act (Law No. 11.079/2004) ${ }^{3}$ to create a business environment with reduced risks in order to encourage the private capital sector to invest in the financing infrastructure and public service in the country. In addition, the legislation provides safeguards that mitigate these risks and guarantee packages (LIMA and COELHO, 2015). Based on federal law, most states and some municipalities, especially metropolises, have also legislated on the topic.

It should also be noted that there are several studies about PPPs in Brazil and abroad. Below, we highlight the research that served as the basis for this article, according to three main subjects, and that may reference other studies:

1) Studies about concepts, legislation, regulations and forms of evaluation for the design and management of PPPs. Osborne (2000) pioneered PPPs from theoretical perspectives of analysis, highlighting the following case studies: Périco and Rebelatto (2005) discuss the real potential of PPPs in the financing public works and services in Brazil; Sundfeld (2005) explains concepts, laws, general aspects, types of PPP modalities in Brazil, differentiation from other concession modalities, risks of misuse by the public machine, etc.; Peci and Sobral (2007) present a comparative analysis of the Brazilian PPP model with models used in the British context (PFI/PPP), highlighting similarities and differences between the two; Mesquita and Martins (2008) discuss the regional distribution of priority investments for PPPs, based on logistical conditions for the formation of business networks in the regions and the strategy bias to reduce regional inequalities, focusing on transport systems; Hodge and Greve (2009) evaluate PPPs and highlight results in terms of their effectiveness and cost-benefit ratio; Khanom (2010) explores the definitions of PPPs from

\footnotetext{
${ }^{2}$ Called common concessions.

${ }^{3}$ Called PPPs stricto sensu, receive government transfers through monthly cash payments.
} 
different angles and identifies various characteristics and problems related to these issues; António (2014) analyzes PPPs in the health sector and reflects on some economic and financial aspects; Lima and Coelho (2015) analyze the risk distribution in the formalizations of these partnerships in Brazil; Thamer and Lazzarini (2015) identify and test critical factors for PPPs to advance through the pre-contractual phases; Fiani (2016) ponders transaction costs in infrastructure PPPs and discusses the application of the hybrid arrangement concept; Santos, Souza and Abreu (2018) analyze the process of applying these partnerships in the country.

2) Experiences of PPPs in Brazil. Barbosa, Cabral and Loiola (2009) analyze the risk mitigation process in the Jaguaribe Ocean Disposal System project, which covers Salvador and Lauro de Freitas; Moreira (2012) works from the perspective of territorial development with the case study of the metrorail sector in the Metropolitan Region of São Paulo; Peci, Godoy, Rodrigues et al. (2012) indicate the main factors that influence the adoption of PPPs contracts, working with the cases of the MG-050 highway, the Penal Complex of the Metropolitan Region of Belo Horizonte and the campus of the State University of Minas Gerais (UEMG); Carrera (2014) analyzes the merits of health sector projects in Brazil; Cabral, Fernandes and Ribeiro (2016) research the roles of stakeholders in the implementation of PPPs in Bahia, focusing on experiences in the areas of health, sanitation and sport/culture; Barbosa and Malik (2015) analyze profiles, critical factors, limitations and trends of different health PPP contracts in Brazil; Rodrigues and Zucco (2018) evaluate the experience of the municipality of Belo Horizonte in the construction and operation of school infrastructure through PPPs; Silva, Carvalho and Oliveira (2019) ponder the organizational design of the network of agents involving health PPPs in the Metropolitan Region of Salvador.

3) Experiences of foreign PPPs. Cossalter and Du Marais (2001) compare the introduction of the Private Financing Initiative (PFI) in France and the United Kingdom, including definitions, main contracts, factors and agents involved; Broadbent and Laughlin (2003) provide an overview of PPP/PFI development, addressing issues about the nature, regulation, design and post-project evaluation of these modalities in the United Kingdom, as well as case studies in the United States, New Zealand and Australia; Li, Akintoye and Edwards (2005) analyze the critical success factors for PPP/PFI projects in the UK construction industry; Azevedo (2008) considers PPPs as an instrument for a new public governance in Portugal. Structured with a logic of legal and economic understanding, the author works with five case studies: the Vasco da Gama Bridge, the restructuring of the Urban Water Cycle, road concessions (Scut), the North-South railway axis (Fertagus) and Health PPPs. Zheng, Roehrich and Lewis (2008) investigate the mechanisms of contractual, relational governance, and changes over time in the management of more complex and long-term public-private arrangements. For this, the authors investigate research from different phases - Design-Build-FinanceOperate (DBFO) - of two case studies in the UK: a hospital and an emergency services training center. Irimia-Diéguez and Oliver-Alfonso (2012) analyze the various forms of PPPs in megaprojects in Spain to determine the potential efficiency gains that can be achieved by implementing these models, using a case study of the Seville metro line; World Bank (2013) presents a review of current practices for disclosing information about PPP projects and contracts in eight countries: South Africa, Australia, Brazil, Canada, Chile, India, Peru and the United Kingdom; Araújo and Silvestre (2014) evaluate the relationship between the use of PPPs and the results obtained in the road construction and management sector in Portugal; Bachelet (2014) critically examines the reasons why social concessions were introduced in different parts of the world, especially hospital concessions in Chile; Fernandez, Hillbrecht, Menezes et al. (2015) identify the determining factors of investment and the number of PPP projects in emerging economies from 2005 to 2012; Mouraviev and Kakabadse (2016) analyze concepts, approaches, forms and models of PPPs in different countries; Fuentes (2017) works with the political process of the 2011 PPP Law in Uruguay; Firmino (2018) studies the factors that justify good PPP performances, including those of a political and institutional nature, addressing the performance aspects of road infrastructure in Portugal; The European Union (UE, 2018) provides a special report from the European Court of Auditors (ECA), which presents the results of its audits regarding EU policies and programs or on topics related to the management of specific budgetary domains. 


\section{THE REGULATORY FRAMEWORK IN BRAZIL, ESPECIALLY BAHIA}

Based on the legal definition of the French PPP and the economic meaning of the English PPP (PECI and SOBRAL, 2007), the Law of Public-Private Partnerships of Brazil emerges as a new incentive for the entry of private funds in the financing of public services and infrastructure in the country. This law applies to entities of the direct public administration of the Executive and Legislative branches, municipalities, public foundations, public companies, mixed-economy companies, special funds and other organizations that are directly or indirectly controlled by federal entities (BRASIL, 2004).

Despite common concessions, PPPs involve the payment of pecuniary consideration from the public sector to private partner, thus, it is necessary for private companies to form a special purpose company (SPE); ${ }^{4}$ with trading competition used in the stock exchange and terms of duration, legal investment floor, etc. (SUNDFELD, 2005).

PPPs in Brazil comprise two types of modalities: administrative, which involves monetary consideration from the public to the private sector, and the sponsored one, which covers, in addition to the payments, the fee charged to users. By law, all contracts can only be executed with an amount equal to or greater than $\mathrm{R} \$ 10$ million (Law No. 13.529/2017) and cannot have a payment term of less than 5 years or more than 35 years, even if it includes extensions. In other words, this type of partnership is restricted to high-priority actions that require large investments. Its payment is subject to the provision of the service by the private partner, according to standards defined in the contract. In the end, all assets that make up the concession structure should be returned to the public entity.

Regarding Latin America and in terms of experience in PPPs projects, Brazil is among the highest ranked countries, alongside Chile and Peru (WORLD BANK, 2013). According to the PPP Radar (COSCARELLI, 2020), it is estimated that, in 2019 alone, signed PPP contracts in the country exceeded R\$ 8 billion (11 new projects), totaling more than $\mathrm{R} \$ 177$ billion (120 projects) in various sectors. The states with the highest number of projects being executed in Brazil are Minas Gerais, Rio de Janeiro, São Paulo, Bahia and Ceará (SANTOS JÚNIOR and NOVAES, 2019). ${ }^{5}$

Regarding Bahia, on December 27, 2004, the government created the Public-Private Partnership Program through Law No. 9.290 (BAHIA, 2004), established by the then governor, Paulo Souto (PFL, current DEM). The state law is similar to the aforementioned federal law but differs by proposing mechanisms that do not compromise the state's fiscal balance. The terms of the contracts follow the same standards as federal laws.

The government also created a Management Council for the PPP Program, which is a planned body with competence to approve partnership projects and deliberate for the governor, as well as oversee the supervision and execution of partnerships to offer opinions on contract changes and propose guidelines (BAHIA, 2019c).

In addition to the Management Council, there is the Executive Secretariat of the PPP Program, a support organization for the Management Council, subordinated to the Secretary of Finance, which coordinates and articulates the public administration organs and private partners (BAHIA, 2019c).

Bahia presents its own payment guarantee system for concessionaires, which works as follows: in the amounts received through the State Participation Fund (FPE), transferred by the union through Banco do Brasil (BB) (Payment Agent), there is a blockage of $18 \%$ of this amount (State Law No. 11.477/2009). Then, this amount is transferred to the account of the Bahia State Development Agency S/A (Desenbahia), a financial institution that is directly or indirectly controlled by the Bahian government and whose account is operated by BB. Desenbahia then authorizes BB to transfer the consideration payment established in the concessionaire's contract, and the surplus is returned to the Bahia State Treasury (BAHIA, 2009).

\footnotetext{
${ }^{4}$ It is a business organization model by which a new company, limited company or limited liability company is formed, with a specific objective, that is, whose activity is quite restricted, and in some cases may have a determined period of existence" (SEBRAE, 2019, np).

${ }^{5}$ According to Santos Júnior and Novaes (2019, p. 1-32), in the Metropolitan Region of Belo Horizonte, 52 public-private partnership projects were identified, but 37 were not successful, as they did not result in contract signing. Today, 15 are being executed at the state and municipal levels. In Ceará, 88 projects were identified, of which 1 has already been concluded- the PPP Plácido Castelo Stadium, for the 2014 FIFA World Cup-; 7 are being executed in Fortaleza and São Gonçalo do Amarante; and 80 have not yet been signed. In Rio de Janeiro, projects at the municipal and state levels resulted in 15 PPP plan initiatives, but most have not yet been signed. However, it is important to highlight the PPP Porto Maravilha, which is considered the largest in Brazil in terms of value (around R\$ 7.61 billion), designed to recover urban infrastructure, transport, the environment and historical heritage and cultural aspects of the port region for a period of 15 years; and PPP Olympic Park considered the second largest in the country, which performed works and services for the 2016 Olympics and maintains some urban and sports equipment on site. São Paulo was the first state to sign a PPP contract in the country - the Metro PPP Line 4, in 2006. Since then, 11 more contracts have been signed.
} 
In addition, the government has established a Bahian Partnership Guarantee Fund (FGBP) (State Law No. 12.610/2012), which aims to provide payment guarantees of pecuniary obligations taken by the direct or indirect government administration (DESENBAHIA, 2015), in contracts concluded after that law. The government paid guarantee quotas in cash with the initial amount of R\$250 million (Law No. 12.912/2013). The FGBP is private and has its own assets. It is administered, managed and represented by Desenbahia. BB is the payment and account management agent of FGBP, and Empresa Baiana de Ativos (Bahiainveste) advises Desenbahia by analyzing the feasibility of the guarantees, proposing the most appropriate method of granting guarantees, estimating the value of guarantees, etc. The fund's assets consist of contributions of assets and rights made by the shareholders. Shares are paid in cash, government bonds, Sunday real estate, properties or other rights with equity value (BAHIA, 2012, n.p).

At the municipal level, Salvador also has legal provisions for implementing PPPs: Law No. 9.092/2016 and Decree No. 28.336/2017. Municipal law is similar to federal and state laws, and, like the government of Bahia, the city created a Partnership Management Council (CGP) to analyze, monitor and deliberate PPPs and concession projects, under the administration of the Municipal Treasury Department (Sefaz). To this end, it established the PPP Financial Fund, which has a legal personality, a private nature and its own assets, being responsible for the monthly pecuniary payments of PPP contracts. In addition, it created the Guarantee Fund for Public-Private Partnerships to guarantee payment of contributions made by the municipality (SALVADOR, 2016, n.p).

\section{PUBLIC-PRIVATE PARTNERSHIPS IN BAHIA}

Regarding the number of PPPs in Bahia, up until July 2020 there were 8 in the execution phase and 1 in the contract signing phase, all celebrated by the state government of Paulo Souto (PFL/DEM), Jaques Wagner and Rui Costa (PT). Of these, 4 are from the urban mobility segment, 3 from health, 1 from sanitation, and 1 from culture/sport/leisure (Figure 2).

The first PPP was instituted in 2006: the Submarine Emissary (Jaguaribe Oceanic Disposal System), at the end of Governor Paulo Souto's term. It was the first PPP in the Northeast region, the second in the country, and also the first from this segment in Brazil. The concession contract is administrative type. The concessionaire that won the bid, Consórcio Jaguaribe S/A, is formed by the companies Odebrecht Investimentos em Infraestrutura and Construtora Norberto Odebrecht.

The system encompasses the municipalities of Salvador, Lauro de Freitas, and consists of the "expansion of the Saboeiro Lifting Station, implementation of repression lines, construction of Pre-Conditioning Station and implementation of Terrestrial and Submarine Emissaries" (BAHIA, 2019c, n.p).

Figure 2

PPPs in the execution and contract signing phases in Bahia (July 2020)

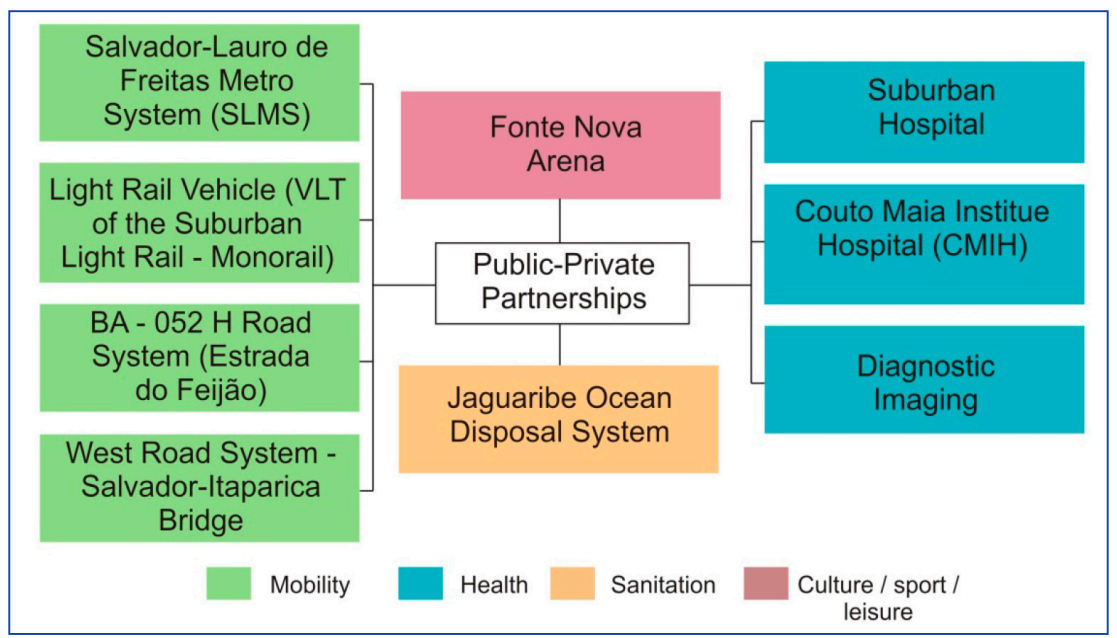

Source: Elaborated by the authors. 
Construction began in June 2008, and operation began in May 2011. The concession is for 18 years, with monthly payments divided into 183 installments, payable through receivables from the Bahian Water and Sanitation Company (Embasa). The project was financed by the Caixa Econômica Federal (CEF), in the amount of R\$ 150 million. In December 2019, the annual consideration was $\mathrm{R} \$ 80.4$ million.

Regarding the PPP of culture/sport/leisure, the Fonte Nova Arena aims to rebuild and operate the football stadium that hosted the 2014 FIFA World Cup. The contract is administrative type, and the concessionaire that won the bid was Fonte Nova Participações S/A (FNP), composed of the construction companies OAS Ltda. and Odebrecht Investimentos em Infraestrutura Ltda. The contract was signed in January 2010, and the concession period is 35 years, which is the maximum under PPP laws. Arena expenses will exceed R\$ 1.5 billion by the end of the contract, and the amount transferred by the state to the concessionaire (annual consideration) was already R\$167.9 million in December 2019.

Regarding the West Road System (SVO), which includes the Salvador-Itaparica Bridge, the bidding notice has been postponed several times, and there have been several discussions and debates since 2010 about the feasibility and environmental and urban impacts of its construction. However, the work has been suggested since the 1960s. In December 2019, it was bid upon and won by the singular proposal of the Chinese giants China Railway 20 Bureau Group Corporation (CR20), CCCC South America Regional Company S.A.R.L (CCCC South America) and China Communications Construction Company Limited (CCCCLTD).

Due to the COVID-19 pandemic, representatives of the consortium did not show up to sign the contract in February 2020. The deadline was extended to the end of July of the same year but needed to be extended again.

The concession project, in the sponsored modality, consists of constructing the bridge under the Todos-os-Santos Bay, which will connect Salvador to Itaparica Island and constructing road accesses in Salvador (4.6 km), a new highway on the island $(21.4 \mathrm{~km})$ and the recovery and expansion of a stretch of the BA-001 highway. The concession period is 30-years, and the value is almost $\mathrm{R} \$ 6$ billion (the highest of all PPPs). The annual consideration will be $\mathrm{R} \$ 56.2$ million and the government will contribute resources totaling $\mathrm{R} \$ 1.5$ billion.

As a new expansion vector, bridge construction will have major impacts in several municipalities, especially in the metropolis and in Vera Cruz and Itaparica, which will require high investment by the State in infrastructure and urban policies.

The other PPPs that are being executed by the State include 3 from the Urban Mobility segment: the Salvador-Lauro de Freitas Metro System, the BA-052 Road System (Estrada do Feijao) and the Light Rail Vehicle (Suburban VLT - monorail), and 3 from the Health segment: Suburban Hospital, Couto Maia Institute Hospital and Diagnostic Imaging. Such PPPs will be analyzed, as case studies, in the next sections.

At the same time, there are 2 projects supervised by the state government: Logistics Platform of São Francisco, which aims to provide the region of Juazeiro, located in the Northern Bahia, with a set of integrated equipment in order to develop activities related to transportation, logistics and distribution of goods to domestic and foreign markets; and Urban Solid Waste Management, which proposes the implementation and operation of a set of activities involving infrastructure and operational facilities of transport, transshipment, treatment of municipal solid waste and environmentally appropriate disposal (BAHIA, 2019c, n.p).

Regarding the city of Salvador, there is a public lighting PPP project. The concession is administrative type, with 20 years of duration, value of $R \$ 1.5$ billion, and provides modernization, optimization, operation, maintenance and remote control of the city's public lighting (SALVADOR, 2018, n.p). The notice was introduced in April 2018, but the Justice Court of Bahia (TJ-BA) suspended the bidding after verifying irregularities in the competition (ARRAZ and FEREIRA, 2018, n.p) and was subsequently revoked by City Hall. After reviewing of the project, new consultation and public hearing, a new notice should be introduced in 2020 or 2021. 


\section{CASE STUDIES OF HEALTH AND URBAN MOBILITY PPPS: PROJECTS, AGENTS AND ARTICULATIONS}

As there are 9 PPPs from different segments that are in execution or contract signing phases in Bahia, this section examined 6 case studies involving the following health and urban mobility PPPs: Suburban Hospital, Couto Maia Institute Hospital, Diagnostic Imaging, Salvador-Lauro de Freitas Metro System, BA-052 Road System (Estrada do Feijão) and Light Rail Vehicle (Suburban VLT - monorail). As previously mentioned, the SVO was not examined because its contract has not yet been signed.

Due to the heterogeneity of contractual arrangements, each PPP was analyzed separately. The objective was to assess and compare the effectiveness of these PPPs - in reference to the preparation of projects - in the implementation and operation of concessions, as well as in the identification of public and private agents involved and their articulations. Box 1 and Box 2 provide a comparative summary of the projects and concessions studied.

Box 1

Comparative characterization of projects and concessions from health PPP case studies in Bahia

\begin{tabular}{|c|c|c|c|}
\hline Variables & $\begin{array}{l}\text { Suburban Hospital } \\
\text { (SH) }\end{array}$ & $\begin{array}{c}\text { Couto } \\
\text { Maia Institute Hospital (CMIH) }\end{array}$ & Diagnostic Imaging \\
\hline Government Scope & State & State & State \\
\hline $\begin{array}{c}\text { Political Management / } \\
\text { Political Party }\end{array}$ & Jaques Wagner (PT) & Jaques Wagner (PT) & Rui Costa (PT) \\
\hline Public Agency Responsible & Sesab & Sesab & Sesab \\
\hline Purpose & $\begin{array}{l}\text { Management and operation } \\
\text { of a hospital unit }\end{array}$ & $\begin{array}{c}\text { Construction, management and } \\
\text { operation of non-assistance services of } \\
\text { the hospital unit }\end{array}$ & $\begin{array}{l}\text { Management and operation of } \\
\text { support services for diagnostic } \\
\text { imaging in } 1 \text { imaging center and } \\
12 \text { public hospital units }\end{array}$ \\
\hline Concession Type & Administrative ("white coat") & Administrative ( "gray coat") & Administrative \\
\hline Contract Signing & 2010 & 2013 & 2015 \\
\hline Competition & $\begin{array}{l}\text { National technical type and } \\
\text { lowest price }\end{array}$ & National type, lowest price & International type, lowest price \\
\hline Bid Winner & $\begin{array}{l}\text { Prodal Health } \\
\text { Consortium S/A }\end{array}$ & $\begin{array}{l}\text { Couto Maia Constructions and } \\
\text { Non-clinical Services Consortium S/A }\end{array}$ & $\begin{array}{l}\text { Brazilian Diagnostic Network } \\
\text { Consortium S/A (RBD Imagem) }\end{array}$ \\
\hline Contract Period & 10 years & 21 years and 4 months & 11 years and 6 months \\
\hline Extension & Possible in the contract & Possible in the contract & Possible in the contract \\
\hline Contract Value & $\mathrm{R} \$ 1$ billion & $\mathrm{R} \$ 843.6$ million & $\mathrm{R} \$ 838.8$ million \\
\hline $\begin{array}{l}\text { Maximum Annual } \\
\text { Contract Payment }\end{array}$ & $\mathrm{R} \$ 103.5$ million & $\mathrm{R} \$ 42.1$ million & $\mathrm{R} \$ 81.8$ million \\
\hline $\begin{array}{l}\text { Current Annual Contract } \\
\text { Payment (December 2019) }\end{array}$ & R\$ 206.7 million & $\mathrm{R} \$ 54.2$ million & $\mathrm{R} \$ 113.1$ million \\
\hline Compensation & $\begin{array}{l}\text { Monthly public payments. } \\
\text { There may also be } \\
\text { extraordinary revenues }\end{array}$ & $\begin{array}{c}\text { Monthly public payments. There may also } \\
\text { be extraordinary revenues }\end{array}$ & $\begin{array}{l}\text { Monthly public payments. } \\
\text { There may also be extraordinary } \\
\text { revenues }\end{array}$ \\
\hline Municipalities involved & Salvador & Salvador & $\begin{array}{l}\text { Salvador, Lauro de Freitas, } \\
\text { Camaçari, Vitória da Conquista, } \\
\text { Jequié, Ilhéus and Guanambi }\end{array}$ \\
\hline $\begin{array}{l}\text { Need for expropriations } \\
\text { and/or removals? }\end{array}$ & Yes & Yes & No \\
\hline $\begin{array}{l}\text { Main Public Agents or } \\
\text { International Agencies }\end{array}$ & $\begin{array}{l}\text { Sesab, Sefaz, Saeb, Seplan, } \\
\text { PGE, Casa Civil, Desenbahia, } \\
\text { BB and BNDES }\end{array}$ & $\begin{array}{c}\text { Sesab, Sefaz, Saeb, Seplan, } \\
\text { PGE, Casa Civil, Desenbahia, } \\
\text { BB and Opas }\end{array}$ & $\begin{array}{l}\text { Sesab, Sefaz, Saeb, Seplan, } \\
\text { PGE, Casa Civil, Desenbahia, } \\
\text { BB and BNDES }\end{array}$ \\
\hline $\begin{array}{l}\text { Main Private Agents or } \\
\text { International Financial } \\
\text { Institutions }\end{array}$ & $\begin{array}{c}\text { IFC, BID, Grupo Promédica, } \\
\text { Dalkia do Brasil (Vivante) } \\
\text { and Accenture do Brasil } \\
\text { Ltda. }\end{array}$ & $\begin{array}{c}\text { MRM Construtora Ltda. (Metro } \\
\text { Engenharia e Consultoria Ltda.), SM } \\
\text { Assessoria Empresarial and Gestão } \\
\text { Hospitalar Ltda., Accenture do Brasil Ltda. }\end{array}$ & $\begin{array}{l}\text { IFC, BID, Antares Consulting, } \\
\text { Manesco Advogados, Alliar, Fidi, } \\
\text { Philips Medical Systems Ltda. } \\
\text { and Accenture do Brasil Ltda. }\end{array}$ \\
\hline
\end{tabular}

Source: Elaborated by the authors. 
Box 2

Comparative characterization of projects and concessions from urban mobility PPP case studies in Bahia.

\begin{tabular}{|c|c|c|c|}
\hline Variables & $\begin{array}{l}\text { Salvador-Lauro de Freitas } \\
\text { Metro System (SLMS) }\end{array}$ & $\begin{array}{l}\text { BA-052 Road System } \\
\text { (Estrada do Feijao) }\end{array}$ & $\begin{array}{l}\text { Light Vehicle Road - } \\
\text { Suburban VLT (monorail) }\end{array}$ \\
\hline Government Scope & State & State & State \\
\hline $\begin{array}{l}\text { Political Management / } \\
\text { Political Party }\end{array}$ & Jaques Wagner (PT) & Rui Costa (PT) & Rui Costa (PT) \\
\hline Public Agency Responsible & Sedur/CTB & Seinfra/Agerba & Sedur/CTB \\
\hline Purpose & $\begin{array}{l}\text { Implementation and operation } \\
\text { of the Metro system }\end{array}$ & $\begin{array}{l}\text { Operation, maintenance and } \\
\text { revitalization of the BA-052 } \\
\text { Road System and construction } \\
\text { of bridge-crossing over the } \\
\text { São Francisco River between } \\
\text { the municipalities of } \\
\text { Xique-Xique and Barra }\end{array}$ & Implementation and operation \\
\hline Concession Type & Sponsored & Sponsored & Sponsored \\
\hline Contract Signing & 2013 & 2018 & 2019 \\
\hline Competition & National type lowest price & International type lowest price & National type lowest price \\
\hline Bid Winner & CCR Metrô Bahia & $\begin{array}{l}\text { Estrada do Feijão Bahia } \\
\text { Consortium }\end{array}$ & Skyrail Bahia Consortium \\
\hline Contract Period & 30 years & 20 years & 20 years \\
\hline Extension & Possible in the contract & Possible in the contract & Possible in the contract \\
\hline Contract Value & $\mathrm{R} \$ 5.7$ billion & $\mathrm{R} \$ 1.6$ billion & $\mathrm{R} \$ 2.8$ billion \\
\hline $\begin{array}{l}\text { Maximum Annual } \\
\text { Contract Payment }\end{array}$ & $\mathrm{R} \$ 127.6$ million & $\mathrm{R} \$ 11$ million & $\mathrm{R} \$ 152.9$ million \\
\hline $\begin{array}{l}\text { Current Annual Contract } \\
\text { Payment (December 2019) }\end{array}$ & $R \$ 291.737 .320,00$ & - & - \\
\hline Compensation & $\begin{array}{c}\text { Compensation fee, user fee, } \\
\text { monthly public payments } \\
\text { and contribution of resources. } \\
\text { There may also be } \\
\text { extraordinary revenues }\end{array}$ & $\begin{array}{l}\text { Monthly public payments, } \\
\text { toll rates and contribution of } \\
\text { resources at the government's } \\
\text { discretion. There may also be } \\
\text { extraordinary revenues }\end{array}$ & $\begin{array}{l}\text { Compensation fee, user fee, } \\
\text { monthly public payments } \\
\text { and contribution of } \\
\text { resources. There may also be } \\
\text { extraordinary revenues }\end{array}$ \\
\hline Municipalities Involved & Salvador and Lauro de Freitas & 18 municipalities & Salvador and Simões Filho \\
\hline $\begin{array}{l}\text { Need for expropriations } \\
\text { and/or removals? }\end{array}$ & Yes & Yes & Yes \\
\hline $\begin{array}{l}\text { Main Public Agents or } \\
\text { International Agencies }\end{array}$ & $\begin{array}{c}\text { Sedur, CTB, Sefaz, Saeb, Seplan, } \\
\text { PGE, Casa Civil, Desenbahia, } \\
\text { BB, BNDES and CEF }\end{array}$ & $\begin{array}{c}\text { Seinfra, Agerba, Sefaz, Saeb, } \\
\text { Seplan, PGE, Casa Civil, } \\
\text { Desenbahia and BB }\end{array}$ & $\begin{array}{l}\text { Sedur, CTB, Sefaz, Saeb, } \\
\text { Seplan, PGE, Casa Civil, } \\
\text { Desenbahia, BB, CEF, } \\
\text { Bahiainveste and Sudene }\end{array}$ \\
\hline $\begin{array}{l}\text { Main Private Agents or } \\
\text { International Financial } \\
\text { Institutions }\end{array}$ & $\begin{array}{c}\text { Andrade Gutierrez, Camargo } \\
\text { Corrêa e Soares Penido, } \\
\text { Queiroz Galvão and Accenture } \\
\text { do Brasil Ltda. }\end{array}$ & $\begin{array}{l}\text { Paviservice e SVC Construções, } \\
\text { IFC and Miga }\end{array}$ & $\begin{array}{c}\text { BYD Brasil, Metrogreen } \\
\text { do Brasil and Accenture do } \\
\text { Brasil Ltda. }\end{array}$ \\
\hline
\end{tabular}

Source: Elaborated by the authors. 


\section{Suburban Hospital PPP}

The Suburban Hospital is dedicated to providing medium and high complexity healthcare services, focused on urgency and emergency. It is located in Periperi, a populous and poorly favored neighborhood in Salvador, and was constructed by the state government under Jaques Wagner in 2008, before the PPP was instituted.

The private Bahian company, MRM Construtora, built the hospital, with a total investment of over $\mathrm{R} \$ 50$ million paid by the public sector. The land was purchased by the state for $\mathrm{R} \$ 600,000$, in the Environmental Protection Area (APA) of the Copper Basin. After families residing in the protection area found out that a hospital was going to be built there, conflicts and negotiations occurred, with subsequent removal of these families (CARRERA, 2014).

With the management, operation and equipment of the hospital in mind, the government preferred to pass responsibility on to the private sector, instituting Brazil's first health PPP. This happened after the Secretary-General of Health, Jorge Solla, visited Spain to obtain information about health PPPs.

At the Suburban Hospital, the project structure counted on the Management Council of the PPP Program of Bahia State and the Executive Secretariat of the PPP Program, previously mentioned, and an Intersectoral Executive Group was created. This type of group is standard for state partnerships. The group was coordinated by the Department of Health (Sesab) and composed of the Finance Secretary (Sefaz), Administration Secretary (Saeb), Planning Secretary (Seplan), State Attorney General (PGE) and Civil Office.

For project structuring, which was unprecedented in the country, a consulting agreement was signed with the Brazil PSP Development Program (PFPP), an organization composed of the International Financial Corporation (IFC, branch of the World Bank), the National Bank for Economic and Social Development (BNDES) and the Inter-American Development Bank (IDB). It is emphasized that, for the construction and design of this PPP, several agents were hired by the government and the consulting company to prepare technical reports. With the project ready and approved by the governor, a public consultation was opened and, soon after, BM \& FBovespa was contracted for the auction.

The IFC, Banco do Nordeste Brasil S/A (BNB) and BNDES released a letter expressing interest (comfort letter) in providing financial support to the winning bidder. At the auction, in a national competition with a lower price, 2 concessionaires submitted proposals: Prodal Saúde S.A., composed of the companies Promédica Patrimonial S.A. and Dalkia Brasil S.A., and the Salvador Health Consortium, formed by SMA Empreendimentos e Participações S.A. and Facility Participações S.A.

The Salvador Saúde consortium, however, presented an irregular economic proposal, above the limit defined in the public notice, and was disqualified. Therefore, the Prodal Saúde Consortium won without effective competition. The administrative type concession contract was signed in May 2010, and the hospital began service in September of the same year.

Conditioned in a contract, Prodal Saúde had to reimburse BM\&FBovespa for the auction, and the government and the Brazil PSP Development Program for structuring the project. The amounts of $R \$ 400,000, R \$ 350,000$ and US\$ 1 million were paid, respectively.

Prodal Saúde was initially composed of the companies Grupo Promédica and Dalkia do Brasil. The latter, with French capital, was presented to Promédica by Siemens. Siemens' wanted to provide some diagnostic imaging equipment to the hospital (CARRERA, 2014). In 2013, Dalkia do Brasil was purchased by Vivante, a company created by investment funds Axxon Group (from Brasil) and Marceau Finance (from French capital) and by minority investors.

The main partners of Promédica Group, the largest health company in Bahia, are José Oliveira and Tereza Valente (widow of the Promédica founder, Jorge Valente Filho, and former daughter-in-law of Jorge Valente, doctor who created the Bahian School of Medicine and Public Health). They are spouses and partners of several companies in the state, especially linked to the private health sector, such as the Jorge Valente Hospital, the Cidade Hospital, the Datalab laboratory and the health insurance provider (Promédica).

The Prodal Saúde consortium invested the equivalent of R\$36 million. The concession operation was financed by BNDES and the concessionaire is entirely responsible for it. The total value of the concession is R\$ 1 billion. However, until the end of the contract, this amount will increase since the value of the loan varies according to the fulfillment of quantitative and performance indicators of the concessionaire. In the contract, the maximum annual consideration was $\mathrm{R} \$ 103.5$ million. 
However, in 2019 alone, total expenses reached R\$ 206.7 million (BAHIA, 2019a). In addition to the consideration, the consortium may have extraordinary revenue stemming from advertising and communication.

The administrative contract modality is "white coat" (unique to Brazil) type, that is, the concessionaire is responsible for building and equipment management and medical care. The concession period is 10 years and may be extended. At the end of the contract, all assets of the hospital have to be legally covered by the state government, as in in all other PPPs.

\section{Couto Maia Institute Hospital PPP}

The Couto Maia Institute Hospital is "the largest and most modern hospital specialized in infectious diseases in Brazil" (BAHIA, 2018c), and was inaugurated in July 2018 after the merger of two hospitals: Hospital Dom Rodrigo de Menezes (HDRM) and Hospital Especializado Couto Maia (HECM).

CMIH was built where HDRM, a former leprosarium, was located in the Cajazeiras (Águas Claras) neighborhood of Salvador. The land belongs to the state and was acquired in 1938 by the governor Juracy Magalhães. On the other hand, the HECM, located in Monte Serrat, was temporarily deactivated. The building, which dates back to 1853, will be used for other activities and offer palliative care to terminal patients with $<6$ months to live. For this, it will be reformed (investment of $R \$ 10$ million). Additionally, its name will be changed to Monte Serrat Hospital (CORREIO, 2019).

The structuring of the PPP project counted on the Management Council of the PPP Program of Bahia State and the Executive Secretariat of the PPP Program (as previously mentioned) and an Intersectoral Executive Group was created (same organs as the HS PPP).

The Brazil PSP Development Program did not use consultancy to structure the project as in the HS project, but economic consulting was used through the Pan American Health Organization (PAHO). The project was based on the Suburban Hospital PPP, Metropolitano Barreiro Hospital and Primary Health Care of Belo Horizonte PPP and the Sao Paulo Health PPP. There was no need for an environmental license.

After public consultation, the auction was held at BM\&FBovespa, contracted for $\mathrm{R} \$ 400,000$. The concessionaire Couto Maia Constructions and Non-clinical Services Consortium, formed by MRM Construtora Ltda. and by SM Assessoria Empresarial e Gestão Hospitalar Ltda. won the bid, assisted by Bradesco Securities and Exchange Broker S/A.

The concession contract, signed in May 2013, is administrative and "gray coat" modality, that is, the concessionaire is responsible for building and administrative management, but hospital medical care is controlled by the state. Unlike the Suburban Hospital, the concessionaire built the $\mathrm{CMIH}$ Hospital.

The concession contract is effective for 21 years and 4 months, with 1 year and 4 months of investments, pre-operational activities and 20 years of operation. The term may be extended to a maximum of 35 years. The value of the contract was $\mathrm{R} \$ 843.6$ million and was reduced to $\mathrm{R} \$ \mathbf{7 5 1 . 3}$ million after an addendum in 2017. Compensation is carried out on the basis of monthly public consideration and extraordinary revenues. The annual consideration in December 2019 was $\mathrm{R} \$ 54.2$ million, and contractual supervision is performed by Sesab, with the help of the Independent Verifier, executed by Accenture do Brasil Ltda.

MRM Construtora, the company that makes up the concessionaire and built the Suburban Hospital, specializes in constructing public equipment and infrastructure and sanitation. It belongs to the Bahian family of former federal deputy Félix Mendonça, with the siblings Félix Mendonça Filho, current federal deputy, president of the PDT in Bahia and president of the Chamber's Science and Technology Commission; and Andrea Mendonça, former councilwoman of Salvador, former Secretary of Agriculture in the state and current President of the Commercial Board of the State of Bahia (Juceb).

The corporate composition of the partnership was modified in 2016. MRM Construtora relinquished all of its shares to Metro Engenharia e Consultoria Ltda. On its website, the company presents a vast portfolio of activities, having among its biggest clients the state government and municipalities, including the municipalities of the Metropolitan Region of Salvador: Lauro de Freitas, Madre de Deus and São Francisco do Conde. The company is managed by Mauro Prates, cousin of the former mayor of Salvador and current state deputy and manager of the Municipal Health Department of Salvador, Léo Prates (DEM). The SM Assessoria Empresarial e Gestão Hospitalar has a long history of technical and managerial support services in public hospitals in Bahia. 


\section{Diagnostic Imaging PPP}

Regarding the PPP Diagnostic imaging, there was another technical cooperation agreement between the government and the Brazil PSP Development Program to conduct technical studies for the project organization. Consultancy from the Spanish company Antares Consulting and the company Manesco Lawyers was used, and the project was structured by Management Council of the PPP Program of Bahia State and the Executive Secretariat of the PPP Program.

The administrative concession was won by the Rede Brasileira de Diagnóstico S/A (RBD Imagem), composed of the Centro de Imagem e Diagnóstico S/A (Alliar), Fundação Instituto de Pesquisa e Estudos de Diagnóstico por Imagem (Fidi) and Dutch Philips Medical Systems Ltda. Conditioned in the contract, RBD Imagem had to reimburse the Brazil PSP Development Program with US\$2.3 million for project structuring, as well as compensate BM \& FBovespa.

The contract provides almost $\mathrm{R} \$ 1$ billion to the private partner for the management and operation of 12 bioimaging units in public hospitals throughout Bahia. There is also a remote center in Salvador that reports to the units and operates 24 hours a day, seven days a week. The concession was financed by IFC, which had already submitted a comfort letter before the bidding. The exams performed are x-ray, mammography, computed tomography and magnetic resonance imaging (Box 3).

\section{Box 3}

Location of bioimaging units in Bahia and types of tests performed at the units*

\begin{tabular}{|c|c|c|}
\hline Units & Municipality & Tests \\
\hline Hosp. Geral do Estado (HGE) & Salvador & $\begin{array}{l}\text { Computed tomography and } \\
\text { magnetic resonance imaging (24h) }\end{array}$ \\
\hline Hosp. Geral Roberto Santos & Salvador & $\begin{array}{l}\text { Computed tomography and } \\
\text { magnetic resonance imaging }(24 \mathrm{~h})\end{array}$ \\
\hline Hosp. Geral Ernesto Simões Filho & Salvador & CT scan, MRI and x-ray (24h) \\
\hline Centro Estadual de Oncologia (Cican) & Salvador & $\begin{array}{c}\text { X-ray, mammography and COMPUTED t } \\
\text { omography }(12 \mathrm{~h})\end{array}$ \\
\hline Hosp. Espec. Octávio Mangabeira & Salvador & X-ray and CT scan (12h) \\
\hline Hosp. Geral Menandro de Faria & Lauro de Freitas & Computed tomography and x-ray (24h) \\
\hline Hosp. Geral de Camaçari & Camaçari & X-ray and CT scan (24h) \\
\hline Hosp. Geral de Vitória da Conquista & Vitória da Conquista & $\begin{array}{l}\text { X-ray and computed tomography (24h); magnetic } \\
\text { resonance imaging (12h) and mammography }\end{array}$ \\
\hline Hosp. Geral Prado Valadares & Jequié & $\begin{array}{l}\text { X-ray and computed tomography (24h); } \\
\text { and MRI (12h) }\end{array}$ \\
\hline Hosp. Regional Costa do Cacau & Ilhéus & $\begin{array}{l}\text { X-ray and computed tomography (24h); } \\
\text { and MRI (12h) }\end{array}$ \\
\hline Hosp. Regional de Guanambi & Guanambi & $\begin{array}{l}\text { X-ray and computed tomography (24h); } \\
\text { and MRI and mammography (12h) }\end{array}$ \\
\hline
\end{tabular}

* There are 11 hospitals due to the temporary exclusion of $\mathrm{CMIH}$.

Source: Elaborated by the authors based on data from RBD Imagem (2019).

The arrangement term is 11 years and 6 months. As in other partnerships, the compensation of the concessionaire responsible, RBD Imagem, is paid by the monthly public consideration and may have extraordinary revenues. The maximum annual consideration amount reached R\$113.1 million in December 2019.

Regarding the companies that make up the consortium, Alliar (formerly Axial) is the third largest company in diagnostic medicine in Brazil, only behind Dasa and Fleury, and is controlled by the Privat Equity Investment Fund (private equity). Alliar has units spread across 44 cities in 10 Brazilian states. Since 2010, the company has been conducting mergers with several regional companies, such as Cedimagem, Plani, Diimagem, CDB, CDI, Clínica Sabedotti, Clínica São Judas Tadeu, CSD, Ecoclinic, Multilab, Multiscan, Nuclear, Sonimed Diagnósticos, Uni Imagem, Unic and Delfin (ALLIAR, 2019; SCHERER, 2016). 
Delfin, which was from Bahia, became a shareholder of RDB Imagem. In March 2018, the company acquired 30\% of RBD Imagem's share capital, in the amount of $\mathrm{R} \$ 5.3$ million.

The other company in the consortium, Fidi, specializes in managing the imaging diagnostics for the Unified Health System (SUS) and has 75 units throughout the country, mainly in São Paulo. Philips (healthcare), a Dutch multinational, stands out for the technology it uses in healthcare equipment worldwide.

\section{Salvador-Lauro de Freitas Metro System PPP}

The Salvador Metro project started being conceived in 1997. At that time, the city of Salvador began negotiations with the International Bank for Reconstruction and Development (Bird), an institution of the World Bank Group, to finance the work. It was constructed by two main consortia: the Spanish CAF/ICF/Dimetronic and the Metrosal, composed of the companies Andrade Gutierrez, Camargo Corrêa and Siemens. The design phase of the project and unfinished construction lasted 16 years. Corruption scandals also marked this period.

After the government of Bahia took over the work, ${ }^{6}$ the Salvador-Lauro de Freitas Metro System, now covering two troubled cities, was implemented as a PPP in the sponsored modality.

For the layout of the project, a PMI was published in 2011. As in the other PPPs, an Executive Technical Group was created, coordinated by the Department of Urban Development (Sedur) and by the Transport Company of Bahia State (CTB), a state public company linked to Sedur. Several agents were hired for technical studies. Final costs were R\$ 2.5 million (NAVES, 2013).

The concession contract, signed in October 2013, was won by the Companhia do Metrô de Salvador S/A (CCR Metrô Bahia), composed of the companies Andrade Gutierrez, Camargo Corrêa and Soares Penido.

The CCR Group is a large infrastructure company in Latin America and has several business centers in Brazil and abroad, including concessions for federal and state highways, Metro systems, Light Rail Vehicle (VLT), water transport (ferries), as well as national (Belo Horizonte) and international airports (Quiport, Ecuador; Aeris, Costa Rica; CAP, Dutch Antilles; and TAS, Total Airport Services, in the United States) (CCR, 2019).

The first Metro section was inaugurated in 2014, in a test phase for the World Cup, but it did not start commercial operations until 2016. The contract for implementation and operation of the Metro system is 30 years, in the amount of R\$ 5.7 billion. The project was financed by BNDES, with R\$ 406.7 million. Another financing contract was signed between the concessionaire and BNDES, totaling R 2 billion, aiming to supplement resources for additional interventions requested by the government and increase the scope of interventions already included in the contract (NAVES, 2013).

In December 2019, the amount of the annual loan was R\$291.7 million, which is the highest among all PPPs in the state (BAHIA, 2018b). Moreover, the government is authorized (Law No. 12.912/2013) to grant tariff subsidies to the concession. The compensation fee passed on to the concessionaire for providing services was initially $\mathrm{R} \$ 2.10$ per passenger. This value is adjusted annually. In addition, the concessionaire receives the user's fare and can have extraordinary revenues.

There is also a credit incentive with financing from Desenbahia ( $\mathrm{R} \$ 50$ million), with credit line resources from the Social and Economic Development Fund (Fundese). The project has several implementation steps. After each stage is completed, the government grants an investment of $\mathrm{R} \$ 2.2$ billion.

The Bahian Partnership Guarantee Fund, through its administrators Desenbahia and CEF, irrevocably and irreversibly provides a guarantee of faithful fulfillment of the government's pecuniary obligations. Once again, Accenture do Brasil Ltda. is the Independent Verifier, receiving $\mathrm{R} \$ 6.2$ million from the concessionaire for a period of 48 months.

Nowadays, the Metro has two $33 \mathrm{~km}$ long lines (Line 1 - Lapa-Pirajá and Line 2 - North-Airport Access) and transports about 370,000 passengers daily. In the concession, it also includes adaptation/ reform, maintenance and operation of the passenger integration terminals provided by the municipality (Rodoviária, Iguatemi, Acesso Norte, Mussurunga and Pirajá). At the same time, other integration terminals were built.

\footnotetext{
${ }^{6}$ The Metro was part of the urban mobility development plan for the 2014 FIFA World Cup, which included Salvador as one of the host cities.
} 
Another section of Line 1, from Pirajá to the Cajazeiras neighborhood, Section 3 of the Metro $(5.5 \mathrm{~km})$, was bid on at the end of 2018 and won by the Construtora Queiroz Galvão Consortium, after the CCinfra-TSEA-EPC consortium was disabled because Camargo Corrêa was already part of the current modal concessionaire, CCR Metrô Bahia. The government is responsible for this construction. The work is scheduled for 30 months and will be financed, with the counterpart of the state, by the Pro-Transport FGTS program of the CEF/Ministry of Cities.

The current governor of Bahia, Rui Costa, has already announced that studies will be conducted to assess whether or not it is feasible for new Metro stations to be technically and economically implemented. The new stretch would be approximately 3 kilometers long, with 4 underground stations connecting the neighborhoods of Politeama, Campo Grande, Graça and Barra (BAHIA, 2019b).

\section{BA-052 Road System PPP}

The BA-052 Road System (Estrada do Feijão) aims to requalify and maintain the state highway that cuts through 18 municipalities of Bahia, totaling $548 \mathrm{~km}$ in length. This is an important route for the flow of agricultural production in the state.

The works cover 2 sections - Feira de Santana-Xique-Xique $(462 \mathrm{~km})$ and Xique-Xique-Barra $(85 \mathrm{~km})$ - and the construction of a road bridge $(1 \mathrm{~km})$ over the São Francisco River that will connect the municipalities of Barra and Xique-Xique. Today, this route is made by craft ships.

The design, which was unprecedented in the country, involved the Methodology of Recovery and Maintenance Contract (Crema), established with the participation of the World Bank. Modeling was also performed by the IFC, which hired different specialized consultants for technical studies. The final compensation cost was set at $\$ 1.2$ million. The concession provides a counterpart to the financing by the World Bank, with a Letter of Intent from the Multilateral Investment Guarantee Agency (Miga), for investment coverage. At the same time, BNB expressed interest in financing the concession. According to Sefaz's Executive Secretary of PPP, Rogério Princhak, the concession "is the first Sponsored PPP with legislative authorization" (DESENBAHIA, 2019, n.p).

The Estrada do Feijão Bahia Consortium, formed by the companies Paviservice and SVC Construções, won the bid. The contract value is R\$ 1.6 billion over 20 years of sponsored concession. The total annual maximum compensation is $\mathrm{R} \$ 11$ million. At the government's discretion, the concession may have a total contribution of resources of $\mathrm{R} \$ 54.3$ million.

The contract is supervised by the State Agency for Regulation of Public Services of Energy, Transport and Communications of Bahia (Agerba). The concessionaire will have to pay the agency $R \$ 600,000$ per year.

\section{Light Rail Vehicle (Suburban VLT) PPP}

The Light Rail Vehicle will replace the suburban train in Salvador, which is $13 \mathrm{~km}$ long and has 10 stations, and circulates precariously from Paripe to the Calçada neighborhood.

The contract only specifies that a VLT will be implemented but could be "another equivalent mode of public transportation on a rail or guide that supports, stabilizes and guides it, powered by electric propulsion and with transport capacity of at least 600 [...] passengers by composition" (BAHIA, 2019c). Therefore, it will not be a VLT, but an elevated monorail.

The technical and economic-financial arrangement of the project was carried out by Bahiainveste and Accenture do Brasil Ltda. The final cost of reimbursement was R\$3.1 million. Like all other PPPs, an Intersectoral Working Group was created to monitor the words, led here by Sedur. Several agents were paid, such as works with operational alternatives for line implementation, to TTC Engenharia de Tráfego e de Transportes Ltda., in the amount of R\$ 65,000; and consultancy and advice about the legal modeling of the project, to Manesco, Ramires, Perez, Azevedo Marques - Law Firm, in the amount of R\$380,000.

The bid for implementation and operation of the monorail was won by the Skyrail Bahia Consortium, led by the Chinese company Build Your Dreams (BYD Brasil), a global giant including Metrogreen in Brasil. The concession is sponsored type, and construction forecast is 24 months.

BYD is China's largest manufacturer of electric vehicles and a monorail specialist. The company has signed a series of agreements with several countries, such as the Philippines, Egypt, Cambodia and Morocco. In addition, it has been negotiating with countries in North and South America, including the United States (BLOOMBERG NEWS, 2018). 
According to the concession project, the monorail will be $19.9 \mathrm{~km}$ long and have 22 stations. It will connect the commercial region of Salvador to São João Island, bordering the metropolis and the municipality of Simões Filho, and will be integrated with Lines 1 and 2 of the Metro. It must serve the peripheral region of Salvador that covers 22 neighborhoods, with an estimated population of 600,000 inhabitants.

The transportation will have the capacity to transport about 150,000 passengers a day. The value of the contract is $R \$ 2.8$ billion. The government will give $\mathrm{R} \$ 100$ million to the concessionaire (resource contribution) until the end of construction, using FPE resources. Once ready, it will pay $\mathrm{R} \$ 152.9$ million, the maximum annual payment amount, for 20 years (contract time).

The concessionaire will also receive compensation and user fees, as well as extraordinary revenues. The compensation fee was initially established at $R \$ 2.20$ per passenger, to be paid to the concessionaire by the government, and will be adjusted annually after the monorail is fully operational. Public payments will be paid through the FPE. There is also the guarantee of faithful compliance with the contract through quotas of the Guarantee Fund. The fund even assumes the role of sponsor.

Phase 2 of the project includes works for future implementation of the section, with 4 stations, which will connect the monorail to Line 1 of the Metro (North Access Station). Governor Rui Costa announced that the monorail (Phase 3) will be extended to the municipalities of Camaçari, Simões Filho, Candeias and Dias d'Ávila. Phases 2 and 3 of the project will only be carried out after the addendum is added to the contract and the economic-financial balance is restored.

The project consultation was approved by the Collegiate Board of Sudene. Total investment will exceed $R \$ 2.8$ billion, with a probable contribution of more than $\mathrm{R} \$ 642$ million from the Northeast Development Fund (FDNE).

\section{ANALYSIS OF URBAN MOBILITY AND HEALTH PPPS IN BAHIA}

This section aimed to analyze the PPPs (through case studies) in Bahia, which provides a greater understanding about the complexity of these organizational arrangements. For this, we used several important studies cited in the literature review, in addition to data and documents, content analysis of contracts for urban mobility and health partnerships and semi-structured interviews with people linked to the state government and concessionaires.

As methodology, thematic-analytical categories were defined as: (i) characteristics, (ii) regulatory framework, (iii) guarantees and credibility, (iv) structuring of projects, (v) relationship between entities, (vi) capital invested and compensation system, (vii) responsibilities and risk allocation, (viii) problems and specific conflicts.

Thus, when analyzing these categories, one of the common characteristics for contracts in Bahia was the governmental sphere. That is, all PPPs are executed by the state, that is, there are no contracts operating at federal and municipal levels.

Most bids were of national type-lowest price. Administrative contracts are similar, including equal clauses. The same occurs in the sponsored modality.

Almost all the projects are concentrated in the metropolis and municipalities of the Metropolitan Region of Salvador. Other municipalities are only included in the Diagnostic Imaging and Estrada de Feijao PPPs.

Regarding contracts, it is well known that they follow the legislation and, in general, include the definitions of contractual terms, performance indicators, payment mechanisms and guarantees, benefit sharing, risk distribution, sanctions, penalties, among others.

It is noteworthy that, thanks to the long duration - between 10 (SH) and 35 years (Fonte Nova Arena) - and, consequently, to the risks involved, economic and financial models established in previous studies are included in these contracts. The planned compensation system represents a balance between the burden and the bonus of all phases of the concession, i.e. the financial liabilities of the private agents involved are covered by the state and specified in the contracts, which guarantees a profit margin for the concessionaire. Currently, all the contracts represent a total of $\mathrm{R} \$ 20$ billion. At the end of the concession, this total will be even higher. In 2019 alone, the government spent almost R\$ 1 billion in annual pecuniary payments transferred to concessionaires through the State Participation Fund, without counting resources and compensation fees. 
Concerning the regulatory framework, Bahia was the fifth state to legislate this type of concession in the country. Its management board greatly influences the performance of contracts and an executive secretariat coordinates and articulates the entities of the public administration and the private partners.

The range of payment guarantees to the private sector is very solid. As previously mentioned, there is a system of payment guarantees originating from the State Participation Fund, with locking of the amount (18\%) destined for monthly pecuniary payments, in addition to a strong Bahian Guarantee Fund for Partnerships, which provides guarantees of pecuniary obligations taken by the government.

The state has fulfilled its payment obligations to the concessionaires. There are arrangements dating back to 2006. This makes the government credible and attracts new arrangements, corroborating the studies of Fernandez, Hillbrecht, Menezes et al. (2015), which indicate that the good use of these concessions depends on several aspects, including institutional factors, such as credibility and ability to comply with contracts.

Bahia is one of the Brazilian states that stands out in the design and management of PPPs. The projects have well-organized structures, with prepared work groups led by Sesab, Sedur, Sefaz and Seinfra, who have been accumulating expertise during the 14 years that the Bahian concessions have been implemented. However, there is still a strong external dependence on consultants and specialists in different areas, according to the literature as Firmino (2018), which warns of this dependence among Portuguese PPPs, given the complexity of structured contracts and their variables involved, as well as the various phases of the contractual execution.

Through the interviews, it was also found that there is generally a good relationship between the various public and private agents involved in the concessions. For example, respondents E2, E9 and E13, stated: "[...] we have some legal disagreements, but we usually get along. We have a good relationship!” (E2); “[...] we are always in direct contact, sometimes on weekends. They always give us everything that we need" (E9). "[...] Today, we have a great relationship. At the beginning of the partnership, we occasionally had problems, but after a while they got settled" (E13).

However, there is a certain insecurity in the public sector due to the long-term impact on the budget and, consequently, due to the state's ability to comply with the Fiscal Responsibility Law, according to Barbosa and Malik (2015). In the interviews conducted, this was very clear in the statements of public officials. The interviewee E10, for example, stated: "[...] we are apprehensive about spending and fiscal targets, and everything has to be disclosed in the Transparency Portal. We have to continue to schedule the contracts. We have a good image regarding PPPs."

The control of the Public Prosecutor's Office (MP) and the Court of Auditors of Bahia State (TCE), which are always raising questions and demanding answers from public authorities about these concessions, in addition to making several recommendations, should be highlighted. Cabral, Fernandes and Ribeiro (2016, p. 335), who analyzed the performance of these controlling stakeholders, hold this same view. For these authors, these agents "tend to present different behavior patterns from demanding and structuring stakeholders. [...] The control role [...], sometimes opposes the other organs belonging to the state structure, often explaining tensions and uncertainties".

In general, private partners assume the costs of regulating projects with municipal, state and federal agencies, including environmental and technical standards. The responsibility of hiring third parties and employees also lies with the private sector. At the Suburban Hospital, which has a the only "white coat" contract in Brazil, the concessionaire is responsible for hiring the professionals who will provide medical care and for the risks. This modality has been greatly criticized by the Physicians Union of Bahia State (Sindimed). For them, doctors feel unsafe, since, although they work in a public unit, they are hired by the private sector, that is, their employment contracts are not through public tenders.

In the case of the Diagnostic Imaging PPP, the hiring of professionals responsible for issuing reports or directly involved in providing services (doctors, nurses and technicians) is the responsibility of the concessionaire. For the Couto Maia Institute Hospital, health care services are provided by the state, under a "gray coat" contract, and consequently assumes all the responsibilities. 
Eventually, the government may assume responsibility for environmental licensing, as was the case with the HS PPP, in which Sesab was responsible for recovering the degraded area (Environmental Protection Area - APA Copper Basin). In Diagnostic Imaging, the inputs of electricity, medicinal gases and water for the bioimaging sectors are government commitments. In the Suburban VLT, the concessionaire makes investments necessary to implement roads, equipment, accessibility and urban real estate in the areas surrounding the monorail network. However, the government is responsible for maintaining interventions.

Expropriations and removals were also provided for in these contracts. In the SLMS and Suburban VLT concessions, specifically, the government is responsible for issuing the decrees necessary for expropriation and removals. Delays in the measures may lead to the restoration of the economic-financial balance in the contract to the concessionaire. The private partner is responsible for submitting a socioeconomic register of owners or occupants of the affected areas, as well as a register detailing the properties, among others. Under governmental supervision, the concessionaire must promote and complete the judicial expropriation proceedings, as well as the provisional occupation of the assets, bearing the payments, costs and expenses resulting from the acts (friendly or judicial). In relation to the Suburban VLT PPP, the limit of this obligation is up to R\$30 million. For the SLMS PPP, the global limit is R\$ 96.6 million. Additional amounts are refunded by the state government.

In all the PPPs studied, the private partners are responsible for obtaining the necessary financing for the operation of the concessions and cannot exempt themselves from any obligation under the contract if they may have problems with the financiers. As a guarantee, concessionaires can provide public payments, remuneration rates (Suburban VLT, SLMS and Estrada do Feijão) or extraordinary revenues, provided that they do not compromise the service provided.

The government creates financing channels between private and financial entities. In fact, in most contracts analyzed before auction, several financial institutions published letters expressing interest (comfort letter) in providing financial support to the winning consortium member, and most financing is provided by public agencies such as CEF, BNDES and Desenbahia.

Among the partnerships, one case deserves to be highlighted regarding this funding issue: the PPP of the Couto Maia Institute Hospital. During the construction period, the works were paralyzed due to lack of financing, which should have been transferred by Desenbahia. The State Attorney General's Office even assessed what judicial action to take. Coincidentally, during this period, the allied political party, PDT, broke from the government (FILHO, 2015). The president of PDT in Bahia, Félix Mendonça Filho, is one of the partners of the MRM Construtora company, which was responsible for constructing the hospital. Failing to obtain financing, the company had to give up the concession contract. Thus, the corporate composition of the partnership was modified in 2016. MRM Construtora ceded all of its shares to Metro Engenharia e Consultoria Ltda., a company managed by Mauro Prates, cousin of the current state deputy and manager of the Municipal Health Department of Salvador, Léo Prates (DEM).

In all contracts analyzed there are specific clauses for responsibilities of risk allocation. The most recent contracts, such as the Suburban VLT and Estrada do Feijão PPPs, are more specific and define each process better. In general, concessionaires are responsible for risks of obtaining licenses, permits and authorizations, bearing costs, delays in meeting deadlines, technology used, engineering related to construction works, perishing, destruction, stealing, burglary, environmental risks, disposal of waste produced by the service and losses caused by these employees, as well as malpractice, labor, tax, social security, accident and procedural issues/expenses. However, in almost all contracts there is a clause indicating that it is up to the grantor (government) to write off the amounts resulting from the eventual problems described in the consideration.

In most cases, the government is also responsible for judicial or administrative decisions that prevent or make it impossible for the concessionaire to provide the service or suspend or interrupt the payment of pecuniary payments and delays or failure to carry out the obligations of concessionaires caused by public agencies.

Concessionaires need to maintain guarantees in compliance with their obligations. Values are stipulated in contract. For example, the contract performance guarantee of the Couto Maia Institute Hospital is R\$ 40 million for the first two years of the concession term, $\mathrm{R} \$ 15$ million for the last two years and $\mathrm{R} \$ 10$ million for the other years. These guarantees are adjusted annually, on the same day that the maximum annual payments are readjusted. If the service is regularized, the amounts are refunded or released by the government. 
However, today we are facing a pandemic (COVID-19) that is causing widespread economic and social consequences worldwide. In Brazil, more precisely in Bahia, it is still not possible to assess the real effects as the contamination and death curves continue to grow. However, the consequences of this pandemic are already being felt in a wide range of sectors, including PPPs, which will consequently have their contracts impacted.

The distributing the risks of the service to be performed allows bidders to evaluate the events whose implications, in case of their implementation, are attributed to them. However, in the event of a pandemic, that is, an extraordinary event with incalculable effects, the risks are characterized by the PPP Law (Law No. 11,079/2004), Articles 4, item VI, and 5, item III, and in the Civil Code (Law No. 10.406/2002) (BRASIL, 2002), in Article 393, as a fortuitous or force-majeure event (the effects are the same). The implications of the pandemic in administrative contracts may also be framed in the "prince's fact", due to the unpredictability of the event.

In contracts, fortuitous events, force majeure or the prince's fact can be covered by insurance, and these risks must be shared among the entities, with a view of endowing the contractual execution with greater predictability. Insurance policies and guarantees are contracted by concessionaires, including the payment of the deductible, in case of using the insurance. State agencies must be co-insured in policies.

However, there is no precedent for the COVID-19 pandemic, making it an unprecedented, unpredictable and uninsurable risk. Thus, by law, the rule of total unpredictability must be allocated to the public administration, that is, the government of Bahia will probably have to bear the high costs of the pandemic, being responsible for the economic and financial rebalancing of PPP contracts.

The form and intensity of this rebalancing will depend on the identification of the impact - those that are too expensive, with extreme advantage to the other, according to the Civil Code - which will depend on careful analysis by the control bodies. To receive the economic-financial rebalancing, the private partner will have to link and document any cost increases, revenue reductions or other actions caused by the pandemic.

Even with impossibility of fulfilling the obligation of the private partner resulting from the direct impacts of COVID-19, private partners may not be liable for non-compliance with the contract or suffer sanctions, e.g., impediment to participate in bids for a period not exceeding 2 years with the state government and fines.

Thus, these contracts, especially those with longer durations, must be modified, which is one of the risk enhancers for this type of organizational arrangement, according to Barbosa, Cabral and Loiola (2009). In addition to economic-financial rebalancing, they may suffer flexibility of investment and performance indicators in the goals and grant payment, as well as increase tariff amounts, renegotiate deadlines, etc.. This requires the utmost attention from control bodies, regulatory agencies and the State Court of Auditors for existing legislation and jurisprudence rules. However, entities must consider the impacts of the pandemic on users (unemployment, decreased income) and public administration, such as reduced tax collection, excessive spending and socioeconomic consequences that are still unknown. The state is responsible for inducing economic growth and reducing the social crisis.

Consensual dialogue between the parties must be maintained, with the aim of outlining measures that mitigate the effects of the crisis and, therefore, ensure the continuity of the contract and effective provision of the service in an efficient manner. However, in reality, major legal problems among the entities involved are expected, leading to numerous and complex bilateral defense instruments. Legal problems are one of the obstacles for the consolidation of PPPs in Brazil, as highlighted by Sundfeld (2005).

In all contracts analyzed, concessions are supervised by Sesab (health), СTB and Agerba (mobility). They are assisted by Independent Verifiers, selected by the public, but remunerated by the private entity. The amount received by the verifiers in the contracts is around R\$1.5 million per year, which is adjusted by the IPCA. Contracts also have an average duration of 3 to 5 years. Accenture do Brasil Ltda. holds contracts with almost all the PPPs analyzed. Regarding the Suburban VLT PPP contract, for example, CTB will receive $\mathrm{R} \$ 400,000$ per month from the concessionaire for the inspection until the monorail is fully operational, and $\mathrm{R} \$ 100,000$ per month after full operation, which is updated annually by the IPCA. For the SLMS PPP, the amount is $\mathrm{R} \$ 250,000$ per month, passed on by the concessionaire to Sedur until full operation, and $0.5 \%$ of the tariff 
revenue effectively inferred by the concessionaire per month, from the full operation of the PPP, until the end of the contract. For SLMS, an Implementation Verifier was hired by the concessionaire to assist the agency. The Concremat-Setec Consortium Manager won the bid, with a contract of R\$ 30.1 million.

Herein, we also highlight some specific problems found in the analysis of these PPPs. In the bidding of the Suburban VLT PPP, for example, the Bahian court suspended the bidding notice several times. In the suspension of June 2017, Judge Sérgio Humberto de Quadros Sampaio, of the 7th Court of the Public Treasury of Salvador, "understood that without the suspension of the bidding process, the public administration runs the risk of signing a contract with clauses that are harmful to the property and public interests" (G1 BAHIA, 2017, n.p). In 2018, the bidding process was carried out, but was seized by the State Court of Auditors because of irregularities in the planning and bidding of the concession. Only in January 2019 was the government able to overturn the injunction that suspended the notice and enforce the result.

For the SLMS PPP, the concession contract, signed in October 2013, was won by the concessionaire Companhia do Metrô de Salvador S/A (CCR Metro Bahia), composed of the companies Andrade Gutierrez, Camargo Corrêa and Soares Penido. The first two participated in the first phase of Metro construction, that is, they were part of the scheme with several irregularities.

There have been recurring complaints from Salvador bus users about fleet reduction after Metro implementation. However, according to an interview with the municipal secretary of mobility, Fábio Mota, on Bahia Noticias website (ARRAZ and FEREIRA, 2018 , n.p), the bus fleet has not decreased, but the transportation system was restructured:

[...] we did not reduce buses; the same amount of buses are still circulating. What we did was optimize the system for two reasons: to avoid competition with the Metro and because of the contract signed by all metropolitan municipalities and the State of Bahia, which establishes a rule with the arrival of the Metro. This contract was part of our public transportation bid, it was part of the Metro bid, and does not allow the bus to pass through more than two Metro stations.

Users of the suburban railway trains of Salvador, which will be replaced by the monorail, are also already complaining about the expected payment of the new charge. The monorail will operate in a system integrated with Metros and buses, with the same value as them. Today, the ticket costs $R \$ 4.20$, which for train users will be a problem since they only pay $\mathrm{R} \$ 0.50$.

In almost all PPPs there are additive terms in their contracts. For example, the HS PPP has 5 terms, the CMIH and Diagnostic Imaging contracts have 4 and the SLMS has 7. Mostly, this is for economic-financial rebalancing. However, according to the literature analyzed, Carrera (2014) points out this problem based on an interview with the BNDES team:

[...] some companies win an auction with a very aggressive proposal and already start hiring lawyers to figure out how they are going to ask for economic-financial balances. [...] the concessionaires look for loopholes in the contract to prove that there was imbalance caused by a risk that was not their responsibility. [...] in the case of the Suburban Hospital, the state was not prepared for this to happen. The contract did not include the execution of marginal cash flow, whose logic is to rebalance the accounts only for the event that caused the imbalance and not for the entire project. As a result, in the first years, there was a request for economic and financial rebalancing almost every quarter. Only after some time did the State manage to develop a business plan that was the basis for rebalancing by marginal cash flow (CARRERA, 2014, p. 110).

Nevertheless, we highlight some denunciations of certain specific pro-market practices and some irregularities pointed out by newspapers, public agencies and trade unions:

1) In 2017, the Public Prosecutor's Office of Bahia State (MPC-BA) opened an investigation to investigate allegedly irregular payments in the amount of $R \$ 355.2$ million by the state regarding public payments paid to 3 public-private partnerships: the Suburban Hospital, Fonte Nova Arena and the Salvador-Lauro de Freitas Metro System. The payments were improperly authorized by Desenbahia, and, according to the MPC-BA, this was not a one-off failure, but a systemic irregularity, showing weaknesses in the control of these partnerships (SANTOS, 2018). 
2) In 2018, the Federal Police (PF) also served search and seizure warrants under Operation Red Card, which investigated alleged irregularities in the Fonte Nova Arena PPP. Fraud in bidding, overbilling, embezzlement of public funds, corruption and money laundering were investigated. According to PF, the work was overpriced in amounts over R\$ 450 million (FOFANO, 2018, n.p). For the MP, the contract presented astronomical values and an overly long contractual term, 35 years, attributed to excessive and unreasonable gains by means through overpricing included in the public consideration paid by the state (G1 BAHIA, 2018, n.p).

3) In 2017, MPC-BA presented an audit report accompanying the concession contract for the Diagnostic Imaging PPP. The results identified several irregularities, such as non-compliance with the implementation schedule; fewer examinations carried out than foreseen in the targets; delay in carrying out essential works; abnormalities in insurance and guarantees in the economic and financial review of the contract; and deficiencies in the supervision of the concession (BAHIA, 2017).

4) Sindimed has published on its website that several patients were refused care at the Suburban Hospital on a daily basis. The union provides a report on the Metro 1 website about an elderly person with a foot injury and diabetes, i.e., diabetic foot, a condition that requires prolonged hospitalization and is costly. For Sindimed, the hospital would be "applying mercntilist guidelines in the selection of patients who are treated. In practice, the most complex and potentially costly cases are passed over and referred to other units. [...] this is a policy for containing expenses and maximizing the gains earned from the contract" (SINDIMED, 2015, n.p).

Finally, at the heart of the entire context, a question was proposed herein: Who has the greatest responsibilities within the Bahian PPPs system - the public or private sector?

For this, some relevant question were asked, based on the work of Silva, Carvalho and Oliveira (2019): Who drew up the projects? Who financed them? Who pays the financing? Who pays the concession? Who are responsible for the biggest risks? Who operates them? Who makes the decisions? Who controls them? And who guides growth?

The conclusion reached herein agrees with that of Silva, Carvalho and Oliveira (2019), that is, the greatest responsibilities are directed to the public sector. We found that the government of Bahia is largely responsible for preparing projects, and is also the incentive and fundamental agent in this process, since it allows and legitimizes the strategies of private agents, regulates, supervises and creates funding channels, which are mostly carried out by public agencies, and pays the bills through monthly pecuniary payments and resource and remuneration fees.

On the other hand, private agents finance and operate these concessions. Regarding the risk allocation of projects, they are generally shared by the entities, with several mitigating measures for such risks - except for fortuitous cases or unprecedented force-majeure - in addition to insurance, economic-financial rebalancing mechanisms and other guarantees manifested by the intervention of the government of Bahia. The private partner and government also work together in managing and orienting growth.

\section{FINAL CONSIDERATIONS}

Through the national and international literature evaluated, projects and concessions of the PPPs analyzed and interviews, PPPs are undoubtedly an important tool for implementing public policies. In addition, it is clear that Bahia has advanced by providing public services and infrastructure with these partnerships, which involve a variety of public and private and national and foreign agents, forming a dynamic power network.

It is well known that Bahia has assumed great importance in the field of PPP concessions. This state is among those with the most projects of this type currently implemented. Overall, the state is governed well regarding the organization and coordination of the entities responsible for concessions, exhibiting pioneering projects and well-structured contracts.

In theory, most of the state's projects are well regarded. In particular, the Suburban Hospital has won several national and international awards, including those from World Finance, the World Bank and the Infrastructure Journal, as well as the United Nations Public Service (UNPSA). According to Desenbahia (2020, n.p), IFC PPP specialist Tomás Anker stated that "Bahia has a predominant role due to the number of successful PPPs and is seen as a reference in Brazil". 
Access to information about all phases of these arrangements is also greatly important for Bahian PPPs. Most mechanisms used in the different stages of the projects are available at www.sefaz.ba.gov.br/administracao/ppp/index.htm, from the Department of Finance of the Bahia State. Bahia also coordinates, through the PPP Executive Secretariat, based at Sefaz, the PPP Network (www.sefaz.ba.gov.br/scripts/redeppp/default.asp), which brings together managers and specialists from different governmental spheres, as well as funding agencies and international partnerships such as the UN and World Bank.

On the other hand, it is necessary to contend with the number of state PPPs that are being executed or in the contract signing phase, a total of 9. From what is understood, this number is predicted to increase in the near future. Thus, in many cases, Bahia may change from a provider to a regulator of public services. Irregularities presented in this paper are also concerning for the credibility of such contracts and need to be monitored more closely.

This type of partnership is criticized due to the transfer of public assets, risks of signing projects that are not priorities in the long term, e.g., possible contract breeches due to changes in government and the private sector, lack of resources and financing, additive terms in the contract, fortuitous cases and force-majeure, etc. In addition, projects with contracts of 10 to 35 years, such as those in Bahia, raise concerns about the financial obligations of future taxpayers.

By analyzing the PPPs, it is clear that the projects are carried out with political visibility in mind. The state government and the city of Salvador are constantly competing, since their managers are members of opposing political parties (PT and DEM, respectively) and have started to invest and attract maximum amounts of capital to implement new institutional arrangements.

Furthermore, the importance of analyzing the structuring, implementation and functioning of Bahian urban mobility and health concessions is highlighted, considering the public and private agents involved and their interactions, as well as the complexity of these contractual arrangements, which may serve as a basis and/or support for studies of national and international institutional arrangements and for planning and managing public policies. However, there were some limitations that occurred while developing the research, especially in relation to the number of interviews conducted and not being able to interview controlling agents (Public Prosecutor's Office and State Court of Auditors) and people linked to the unions, which lead to a more limited point of view. Similarly, it was not possible to carry out a more in-depth analysis of project designs or of the time and difficulties in implementing these PPPs until reaching operational conditions. Such issues are important for understanding the success or failure of these concessions. Such limitations could be remedied in future studies.

Finally, it is imperative to draw attention to the fact that, only after long-term assessments or the finalization of these contracts can these arrangements, along with their positive and negative effects on society, be more accurately assessed. 


\section{REFERENCES}

ALLIAR. Institucional. São Paulo. 2019. Available at: <http://alliar. com/institucional/>. Accessed on: June 28, 2019.

ANTÓNIO, I. Das parcerias público-privadas no sector da saúde: análise e reflexão sobre alguns aspectos económico-financeiros Revista Electrónica de Direito, n. 2, p. 1-35, 2014.

ARAÚJO, J. F. F. E.; SILVESTRE, H. C. As parcerias público-privadas para o desenvolvimento de infraestrutura rodoviária: experiência recente em Portugal. Revista de Administração Pública, Rio de Janeiro, v. 48, n. 3, p. 571-593, 2014.

ARRAZ, L.; FEREIRA, G. Fábio Mota. Bahia Notícia, Salvador, May 21, 2018. Available at: <www.bahianoticias.com.br/entrevista/573fabio-mota.html>. Accessed on: Jan. 22, 2020.

AZEVEDO, M. E. As parcerias público-privadas: instrumento de uma nova governação pública. 2008. Doctoral Dissertation (Doctor Degree in Legal and Economic Sciences) - Faculdade de Direito, Universidade de Lisboa, Lisboa, 2008.

BACHELET, V. C. Hospital concessions in Chile: where we are and where we are heading. Medwave, v. 14, n. 10, p. 1-7, 2014.

BAHIA. Lei no 9.290, de 27 de dezembro de 2004. Institui o Programa de Parcerias Público-Privadas do Estado da Bahia (PPP Bahia) e dá outras providências. Salvador: Diário Oficial do Estado da Bahia, 2004.

BAHIA. Lei no 11.477, de 1 de julho de 2009. Autoriza a transferência de parcela dos recursos financeiros oriundos do Fundo de Participação dos Estados e do Distrito Federal (FPE)... Salvador: Diário Oficial do Estado da Bahia, 2009.

BAHIA. Lei no 12.610, de 27 de dezembro de 2012. Autoriza o Poder Executivo a criar o Fundo Garantidor Baiano de Parcerias (FGBP), altera as Leis no 9.290, de 27 de dezembro de 2004, e no 7.599, de 7 de fevereiro de 2000... Salvador: Diário Oficial do Estado da Bahia, 2012.

BAHIA. Ministério Público de Contas do Estado da Bahia. Parecer no 000462/2017. Salvador. 2017. Available at: <www.tce.ba.gov.br/ images/parecer_mp_9043_2016.pdf>. Accessed on: July 05, 2019.

BAHIA. PPP do Sistema BA 0-52. Salvador. 2018a. Available at: <https:// cbic.org.br/infraestrutura/wp-content/uploads/sites/26/2018/02/ PPP-Sistema-BA052-Consulta-ública.pdf>. Accessed on: July 10, 2019.

BAHIA. Secretaria da Saúde. Governo da Bahia inaugura maior hospital de doenças infecciosas do Brasil. 2018b. Available at: <www.saude. ba.gov.br/2018/ 07/06/governo-da-bahia-inaugura-maior-hospitalde-doencas-infecciosas-do-brasil/>. Accessed on: July 15, 2019.

BAHIA. Secretaria da Fazenda do Estado da Bahia (Sefaz). PPP Parcerias Público-Privadas. Despesas com PPPs. Salvador. 2019a. Available at: $<w w w . s e f a z . b a . g o v . b r / a d m i n i s t r a c a o / p p p / d e s p e s a s \_p p p s . h t m>$. Accessed on: May 10, 2019.

BAHIA. Secretaria de Comunicação Social. Expansão do metrô até a Barra é debatida na Seplan. Salvador. 2019b. Available at: <www. secom.ba.gov.br/2019/05/148848/Expansao-do-metro-ate-a-Barrae-debatida-na-Seplan.html>. Accessed on: July 04, 2019.

BAHIA. Secretaria da Fazenda do Estado da Bahia (Sefaz). PPP (Parcerias Público-Privadas). Salvador. 2019c. Available at: <www.sefaz.ba.gov. br/administracao/ppp/index.htm>. Accessed on: May 10, 2019.
BARBOSA, A. P.; MALIK, A. M. Desafios na organização de parcerias público-privadas em saúde no Brasil. Análise de projetos estruturados entre janeiro de 2010 e março de 2014. Revista de Administração Pública, Rio de Janeiro, v. 49, n. 5, p. 1143-1165, 2015.

BARBOSA, M.; CABRAL, S.; LOIOLA, E. Mitigação de riscos em PPP: o caso do Emissário Submarino de Salvador, Bahia. Panorama das Contas Públicas, Salvador, v. 1, p. 149-162, 2009.

BLOOMBERG NEWS. Monotrilho em Salvador integra ação mundial de empresa chinesa. Mobilize Brasil, São Paulo, June 05, 2018. Available at: <www.mobilize.org.br/noticias/11034/monotrilho-em-salvadorintegra-acao-mundial-da-byd.html>. Accessed on: Jan. 24, 2020.

BRASIL. Lei no 10.406, de 10 de janeiro de 2002. Institui o Código Civil. Brasília, DF: Diário Oficial da União, Poder Executivo, 2002.

BRASIL. Lei no $\mathbf{1 1 . 0 7 9}$, de $\mathbf{3 0}$ de dezembro de 2004. Institui normas gerais para licitação e contratação de parceria público-privada no âmbito da administração pública. Brasília, DF: Diário Oficial da União, Poder Executivo, 2004

BRASIL. Lei no 13.529 , de 4 de dezembro de 2017. Dispõe sobre a participação da União em fundo de apoio à estruturação e ao desenvolvimento de projetos de concessões e parcerias públicoprivadas; altera a Lei no 11.079... Brasília, DF: Diário Oficial da União, Casa Civil, 2017

BROADBENT, J.; LAUGHLIN, R. Public private partnerships: an introduction. Accounting, Auditing \& Accountability Journal, v. 16, n. 3, p. 332-341, 2003.

CABRAL, S.; FERNANDES, A. S. A.; RIBEIRO, D. B. C. Os papéis dos stakeholders na implementação das parcerias público-privadas no Estado da Bahia. Cadernos EBAPE.BR, Rio de Janeiro, v. 14, n. 2 p. 325-339, 2016.

CARRERA, M. B. M. Parceria público-privada (PPP): análise do mérito de projetos do setor saúde no Brasil. 2014. Doctoral Dissertation (Doctor Degree in Business Administration) - Escola de Administração de Empresas de São Paulo, Fundação Getulio Vargas, São Paulo, 2014.

CCR. Sobre o Grupo CCR. 2019. Available at: <http://www.grupoccr. com.br/grupo-ccr/sobre-o-grupo-ccr>. Accessed on: June 10, 2019.

CCR METRÔ BAHIA. Mapa das linhas. Salvador. 2018. Available at: $<w w w . c c r m e t r o b a h i a . c o m . b r / l i n h a-1 / m a p a-d a-l i n h a>$. Accessed on: April 22, 2019.

COGHILL, K.; WOODWARD, D. Political issues of public-private partnerships. In: HODGE, G.; GREVE, C. (Eds.). The challenge of public-private partnerships: learning from international experience. Cheltenham: Edward Elgar, 2005. p. 81-94.

CORREIO. Antigo Couto Maia irá oferecer cuidados paliativos para pacientes terminais. Correio 24 Horas, Salvador, Apr. 14, 2019. Available at: $<$ www.correio24horas.com.br/noticia/nid/antigo-coutomaia-ira-oferecer-cuidados-paliativos-para-pacientes-terminais $>$. Accessed on: Apr. 14, 2019.

COSCARELLI, B. V. R\$ 26 bilhões em contratos de concessões assinados em 2019 no Brasil. Radar PPP, São Paulo, Jan. 16, 2020. Available at: <www.radarppp.com/blog/r-26-bilhoes-em-contratos-de-concessoesassinados-em-2019-no-brasil/>. Accessed on: Jan. 24, 2020. 
COSSALTER, P.; DU MARAIS, B. La private finance initiative. Paris Institut de la Gestion Déléguée, 2001.

DESENBAHIA. Bahia é referência no país em projetos de PPP. Desenbahia, Salvador, Feb. 26, 2019. Available at: <www.desenbahia. ba.gov.br/Noticias/noticia/8733?title=bahia-e-referencia-no-paisem-projetos-de-ppp>. Accessed on: Jan. 11, 2020.

DESENBAHIA. Regulamento do Fundo Garantidor Baiano de Parcerias (FGBP). Salvador. 2015. Available at: <www.sefaz.ba.gov. br/administracao/ppp/Regulamento_do_Fundo_Garantidor_Baiano_ de_Parcerias.pdf>. Accessed on: May 13, 2019.

EDWARDS, P. et al. Evaluating the operation of PFI in roads and hospitals. Londres: Acca, 2004. (Research Report, n. 84).

FERNANDEZ et al. Impacto dos determinantes das parcerias públicoprivadas em economias emergentes. Planejamento e Políticas Públicas (PPP), n. 44, p. 291-315, 2015.

FIANI, R. O problema dos custos de transação em parcerias públicoprivadas em infraestrutura. Rio de Janeiro: Instituto de Pesquisa Econômica Aplicada, 2016. (Texto para discussão 2.261).

FILHO, M. PGE estuda destrato com empresa de Félix Jr após atraso em obras do Couto Maia. BNews, Salvador, June 30, 2015. Available at: $<$ www.bnews.com.br/noticias/politica/saude/117716,pge-estudadestrato-com-empresa-de-felix-jr-apos-atraso-em-obras-do-coutomaia.html>. Accessed on: June 30, 2019.

FIRMINO, S. I. Fatores críticos de sucesso das parcerias públicoprivadas: aspectos político-institucionais. Estudo de caso das rodovias em Portugal. Revista de Administração Pública, Rio de Janeiro, v. 52, n. 6 , p. 1270-1281, 2018.

FOFANO, A. PF deflagra ação contra irregularidades na construção da Fonte Nova. Metro 1, Salvador, Feb. 26, 2018. Available at: <www. metro1.com.br/noticias/politica/50397,pf-deflagra-acao-contrairregularidades-na-construcao-da-fonte-nova>. Accessed on: Jan. 25, 2020.

FUENTES, G. ¿Reforma silenciosa del Estado?: proceso político de la ley de participación público-privada en Uruguay. Revista de Administração Pública, Rio de Janeiro, v. 51, n. 6, p 1005-1022, 2017.

G1 BAHIA. Hospital Couto Maia muda de endereço e passa a funcionar no bairro de Cajazeiras, em Salvador. G1 Bahia, Salvador, July 06, 2018. Available at: <https://g1.globo.com/ba/bahia/noticia/hospitalcouto-maia-muda-de-endereco-e-passa-a-funcionar-no-bairro-decajazeiras-em-salvador.ghtml>. Accessed on: July 13, 2019.

G1 BAHIA. Justiça suspende licitação do VLT de Salvador pela terceira vez. G1 Bahia, Salvador, Sept. 19, 2017. Available at: <https://g1.globo. com/bahia/noticia/justica-suspende-licitacao-do-vlt-de-salvadorpela-terceira-vez.ghtml>. Accessed on: Jan. 25, 2020.

HODGE, G.; GREVE, C. PPPs: the passage of time permits a sober reflection. Institute of Economic Affairs, Oxford, v. 19, n. 1, p. 33-39, 2009.

IRIMIA-DIÉGUEZ, A. I.; OLIVER-ALFONSO, D. Models of public-private partnerships in megaprojects: the spanish case. Organization, Technology and Management in Construction - An International Journal, v. 4, n. 3, p. 604-616, 2012.

KHANOM, N. A. Conceptual Issues in Defining Public Private Partnerships (PPPs). International Review of Business Research Papers, v. 6, n. 2, p. 150-163, 2010.
LI, B.; AKINTOYE, A.; EDWARDS, P. J. Critical success factors for PPP/PFI projects in the UK construction industry. Construction Management and Economics, v. 23, n. 5, p. 459-471, 2005.

LIMA, C. M. C.; COELHO, A. C. Alocação e mitigação dos riscos em parcerias público-privadas no Brasil. Revista de Administração Pública, Rio de Janeiro, v. 49, n. 2, p. 267-291, 2015.

MESQUITA, A. M.; MARTINS, R. S. Desafios logísticos às redes de negócios no Brasil: o que podem as parcerias público-privadas (PPPs)? Revista de Administração Pública, Rio de Janeiro, v. 42, n. 4, p. 735-763, 2008.

MOREIRA, L. C. As parcerias público-privadas e o desenvolvimento territorial: uma análise do setor metroferroviário na Região Metropolitana de São Paulo. 2012. Master Thesis (Master Degree in Administration) - Universidade Municipal de São Caetano do Sul, São Caetano do Sul, 2012.

MOURAVIEV, N.; KAKABADSE, N. K. Conceptualising public private partnerships: a critical appraisal of approaches to meanings and forms. Society and Business Review, v. 11, n. 2, p. 155-173, 2016.

NAVES, G. A. Sistema Metroviário de Salvador e Lauro de Freitas (Bahia). Radar PPP, São Paulo, 15 out. 2013. Available at: <www. radarppp.com/resumo-de-contratos-de-ppps/sistema-metroviariode-salvador-e-lauro-de-freitas-bahia/>. Accessed on: Jan. 20, 2020.

OSBORNE, S. P. Public-Private Partnerships: theory and Practice in International Perspective. Routledge: London, 2000.

$\mathrm{PECl}$, A. et al. Parcerias público-privadas em Minas Gerais: racionalidade técnica versus política. Contabilidade, Gestão e Governança, v. 15, n. 1, p. 80- 95, 2012.

$\mathrm{PECl}, \mathrm{A}$.; SOBRAL, F. Parcerias público-privadas: análise comparativa das experiências britânicas e brasileiras. Cadernos EBAPE.BR, Rio de Janeiro, v. 5, n. 2, p. 1-14, 2007.

PÉRICO, A. E.; REBELATTO, D. A. N. Desafios das parcerias públicoprivadas (PPPs). Revista de Administração Pública, Rio de Janeiro, v. 39, n. 5, p. 1031-1052, 2005.

RBD IMAGEM. Exames por imagem. Salvador. 2019. Available at: <www.pppimagembahia.com.br/>. Accessed on: May 01, 2019.

RODRIGUES, B.; ZUCCO, C. Uma comparação direta do desempenho de uma PPP com o modelo tradicional de contratação pública. Revista de Administração Pública, Rio de Janeiro, v. 52, n. 6, p. 1237-1257, 2018.

SALVADOR. Lei no 9.092, de $\mathbf{2 6}$ de julho de 2016. Altera, revoga e acrescenta dispositivos da Lei no 6.975, de 27 de janeiro de 2006, que institui o Programa de Parcerias Público-Privadas do Município de Salvador, e dá outras providências. Salvador: Diário Oficial do Município do Salvador, 2016.

SALVADOR. Secretaria de Comunicação. Prefeitura recebe propostas para PPP da iluminação pública de Salvador. 2018. Available at: <www. comunicacao.salvador.ba.gov.br/index.php/todas-as-noticias/52016prefeitura-recebe-propostas-para-ppp-da-iluminacao-publica-desalvador>. Accessed on: May 01, 2019.

SANTOS JÚNIOR, O.; NOVAES, P. Governança local neoliberal: adoção de instrumentos pró-mercado e mudanças regulatórias nos municípios. Observatório das Metrópoles, Rio de Janeiro, Dec. 19, 2019. Available at: <www.observatoriodasmetropoles.net.br/ 
primeiros-resultados-do-projeto-de-pesquisa-sobre-regimes-urbanosparte-ii/>. Accessed on: Jan. 02, 2020.

SANTOS, L. MP abre inquérito para investigar pagamentos à Fonte Nova e metrô. Correio 24 Horas, Salvador, Aug. 11, 2018. Available at: <https://www.correio24horas.com.br/noticia/nid/mpabre-inquerito-para-investigar-pagamentos-a-fonte-nova-e-metro/>. Accessed on: July 14, 2019.

SANTOS, R. F., SOUZA, A. O.; ABREU, S. O canto da sereia na era global: a parceria público-privada no Brasil. Formação, v. 25, n. 46, p. 5-26, 2018.

SCHERER, A. O fundo pátria vai se entender com seus 70 sócios na Alliar? Revista Exame, São Paulo, Mar. 03, 2016. Available at: < https://exame. $\mathrm{com} /$ revista-exame/o-fundo-patria-vai-se-entender-com-seus-70-sociosna-alliar/>. Accessed on: June 30, 2019.

SERVIÇO BRASILEIRO DE APOIO ÀS MICRO E PEQUENAS EMPRESAS - SEBRAE. $O$ que é Sociedade de Propósito Específico (SPE) e como funciona. Brasília. 2019. Available at: <www.sebrae.com.br/sites/ PortalSebrae/artigos/o-que-sao-sociedades-de-proposito-especific o,79af438af1c92410VgnVCM100000b272010aRCRD\#0>. Accessed on: June 30, 2019.

SIEMIATYCKI, M. The theory and practice of infrastructure publicprivate partnerships revisited. In: SYMPOSIA - NEITHER PUBLIC NOR PRIVATE: MIXED FORMS OF SERVICE DELIVERY AROUND THE GLOBE, 2012, Barcelona. Proceedings... Barcelona: Universidad de Barcelona, 2012.

SILVA, M. P.; CARVALHO, S. S.; OLIVEIRA, M. J. S. Desenho organizacional da rede de agentes que envolvem as parcerias público-privadas de saúde na Região Metropolitana de Salvador. Geosul, Florianópolis, v. 34, n. 73 , p. $464-497,2019$
SINDICATO DOS MÉDICOS DO ESTADO DA BAHIA - SINDIMED. Em nome do lucro, hospital do subúrbio nega atendimento. SINDMED, Salvador, Oct. 29, 2015. Available at: <sindimed-ba.org.br/em-nomedo-lucro-hospital-do-suburbio-nega-atendimento $>$. Accessed on: July 04, 2019.

SUNDFELD, C. A. O arcabouço normativo das parcerias públicoprivadas no Brasil. Revista do TCU, n. 104, p. 53-61, 2005.

THAMER, R.; LAZZARINI, S. G. Projetos de parceria público-privada: fatores que influenciam o avanço dessas iniciativas. Revista de Administração Pública, Rio de Janeiro, v. 49, n. 4, p. 819-846, 2015.

UNIÃO EUROPEIA - UE. Parcerias Público Privadas na UE: insuficiências generalizadas e benefícios limitados. Luxemburgo: Tribunal de Contas Europeu, 2018. (Relatório Especial, n. 09/2018). Available at: <https://op.europa.eu/webpub/eca/special-reports/ppp-9-2018/ pt/>. Accessed on: Jan. 04, 2020.

VIGNÉ, J. Procuradoria vai recorrer de liminar que suspendeu PPP da luz em Salvador. Bahia Notícia, Salvador, May 29, 2018. Available at: <bahianoticias.com.br/noticia/222611-procuradoria-vai-recorrerde-liminar-que-suspendeu-ppp-da-luz-em-salvador.html>. Accessed on: Jan. 22, 2020.

WORLD BANK. Disclosure of Project and Contract Informationin PublicPrivate Partnerships. Washington, DC: World Bank, 2013. Available at: <http://documents.worldbank.org/curated/en/190901468159906133/ Disclosure-of-project-and-contract-information-in-Public-PrivatePartnerships-PPPs>. Accessed on: Apr. 14, 2019.

ZHENG, J.; ROEHRICH, J. K.; LEWIS, M. A. The dynamics of contractual and relational governance: Evidence from long-term public-private procurement arrangements. Journal of Purchasing and Supply Management, v. 14, n. 1, p. 43-54, 2008.

Maina Pirajá Silva

ORCID: https://orcid.org/0000-0002-1734-8631

Ph.D. in Geography from the Federal University of Bahia; Full professor in the Graduate Program in Territorial Planning and Social Development and professor of geography at the Catholic University of Salvador; Leader of the gam research group- Metropolitan Areas Study Group, Salvador- BA, Brazil.

E-mail:mainapiraja@yahoo.com.br; maina.silva@ucsal.br

Silvana Sá de Carvalho

ORCID: https://orcid.org/0000-0003-1898-4055

Ph.D. in Geography from the Federal University of Sergipe; Full professor in the Graduate Program in Territorial Planning and Social Development at the Catholic University of Salvador; Leader of the research group GEOPLAN - Geoprocessing Applied to Territorial and Environmental Planning, Salvador-BA, Brazil. E-mail: silvana.carvalho@ucsal.br

Mariana de Oliveira Santana

ORCID: https://orcid.org/0000-0003-2973-7076

Undergraduate and bachelor's degree in Geography from the Catholic University of Salvador; Master's in Territorial Planning and Social Development at the same institution; Researcher at the GAM research group - Study Group of Metropolitan Areas and GEPOGEO- Study and Research Group in Political and Geopolitical Geography, Salvador-BA, Brazil. E-mail: mariana_oliveira018@hotmail.com 